\title{
Circular economy: To be or not to be in a closed product loop? A Life Cycle Assessment of aluminium cans with inclusion of alloying elements
}

\author{
Niero, Monia; Olsen, Stig Irving
}

Published in:

Resources, Conservation and Recycling

Link to article, DOI:

10.1016/j.resconrec.2016.06.023

Publication date:

2016

Document Version

Peer reviewed version

Link back to DTU Orbit

Citation (APA):

Niero, M., \& Olsen, S. I. (2016). Circular economy: To be or not to be in a closed product loop? A Life Cycle Assessment of aluminium cans with inclusion of alloying elements. Resources, Conservation and Recycling, 114, 18-31. https://doi.org/10.1016/j.resconrec.2016.06.023

\section{General rights}

Copyright and moral rights for the publications made accessible in the public portal are retained by the authors and/or other copyright owners and it is a condition of accessing publications that users recognise and abide by the legal requirements associated with these rights.

- Users may download and print one copy of any publication from the public portal for the purpose of private study or research.

- You may not further distribute the material or use it for any profit-making activity or commercial gain

- You may freely distribute the URL identifying the publication in the public portal 


\title{
Circular economy: to be or not to be in a closed product loop?
}

\section{A Life Cycle Assessment of aluminium cans with inclusion of alloying elements}

\author{
Monia Niero*, Stig Irving Olsen \\ Division for Quantitative Sustainability Assessment (QSA), Department of Management Engineering, \\ Technical University of Denmark, Produktionstorvet Building 424, 2800 Kgs. Lyngby (Denmark) \\ * Corresponding author: monni@dtu.dk
}

\begin{abstract}
:
Packaging, representing the second largest source of aluminium scrap at global level, deserves a key role in the transition towards the circular economy. Life Cycle Assessment (LCA) of aluminium products has been typically based on one life cycle considering pure aluminium flows and neglecting the presence of alloying elements and impurities. However, this simplification undermines the potentials of using LCA to quantify the environmental performances of products in multiple loops, as required in the circular economy. This study aims to investigate the effects of including the actual alloy composition in the LCA of aluminium can production and recycling, in order to understand whether a can-to-can (i.e. closed product loop) recycling should be promoted or not. Mass balance of the main alloying elements ( $\mathrm{Mn}, \mathrm{Si}, \mathrm{Cu}, \mathrm{Fe}$ ) was carried out at increasing levels of recycling rate, corresponding to a temporal interval of five years. Different aluminium packaging scrap sources were considered: mixed packaging aluminium scrap and used beverage can scrap. The outcomes of the mass balance were used to quantify the amount of Mn and primary Al that needs to be reintegrated in each scenario according to the recycling rate and this information was further used to perform an LCA of 30 loops of aluminium can production and recycling, based on the actual alloy composition. The LCA revealed that the closed product loop option (considering used beverage can scrap) has lower climate change impacts over the other recycling scenario using mixed Al packaging scrap. The main recommendation from an LCA methodological point of view is to include the idea of multiple co-functions in the functional unit definition. To further improve the environmental performances of the aluminium beverage can sector towards circular economy implementation the key actions are: to reduce the weight of the lid, to develop methods to separate the body and lid at the point of collection, and to investigate the potentials of a closed supply chain loop for aluminium cans in terms of combined environmental and economic value creation.
\end{abstract}

Keyword (max 6): recycling, LCA, aluminum alloys, scrap, used beverage cans, packaging 


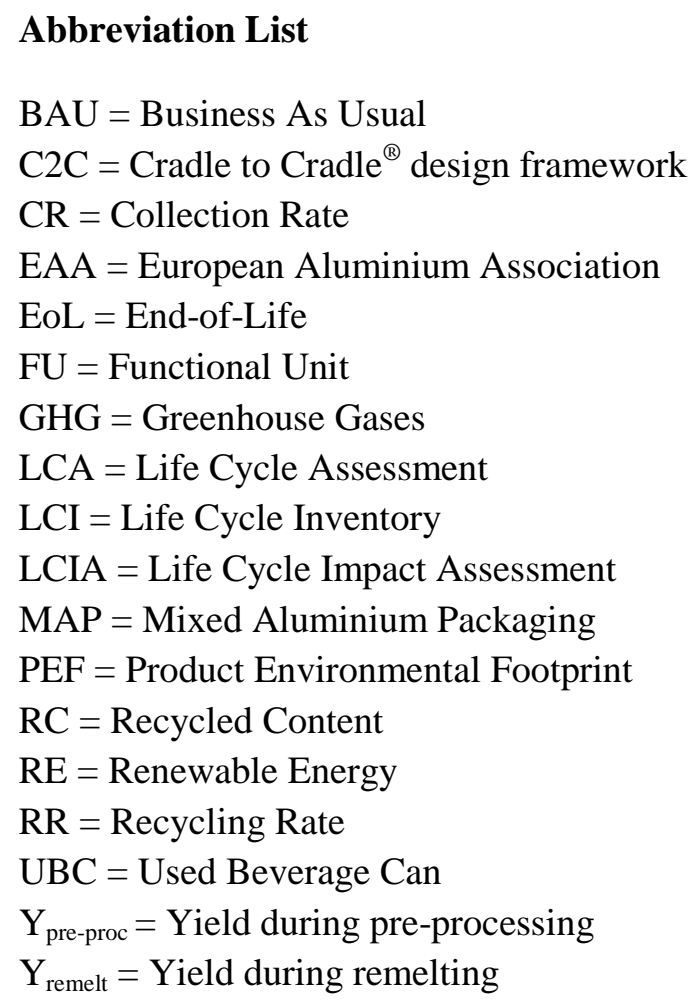




\section{Introduction}

The aluminium industry, as part of the metal industry, is committed to reduce its emissions and energy consumption in the future towards a more sustainable sector (Liu and Müller 2012). Aluminium production is indeed responsible for approximately $1.1 \%$ of global greenhouse gases (GHG) (IEA 2009) and may in the future become limited by access to energy (Sverdrup et al. 2015). The generation of solid waste during aluminium production represents a further element of concern both for aluminium industry and society (EAA 2013).

The largest reduction potential in energy use and GHG emissions is provided through recycling of postconsumer scrap, also called old scrap, which is available mainly in the form of Used Beverage Cans (UBC) and end-of-life (EoL) vehicles (Liu et al. 2012). Aluminium post-consumer scrap is a raw material commodity traded at global level (EAA 2006), which deserves a key role towards the shift from a linear to circular economy (Sevigné-Itoiz et al. 2014). According to the Ellen MacArthur Foundation (EMF) definition, the circular economy aims to decouple economic growth from resource constraints by maximizing use of residuals (EMF 2013). Circular economy can be implemented at different levels, from a single company perspective to a value chain approach, to the global economy. Different overlapping concepts inspired the above-mentioned definition of circular economy, making it a broad vision that has a strong focus on the business strategy (CIRAIG 2015). Besides the market aspects, efficient collection systems need to be built to capture the materials value of goods that are consumed far from their point of origin, as well as design better combinations of goods and packaging, and dramatically increase the attention management gives to recovering value in the post-use stages of the supply chain (EMF 2013).

Packaging represents the second largest source of aluminium scrap at global level (Muchová and Eder 2010). In the context of the EU action plan for the circular economy (EC 2015a), clear targets for waste reduction are presented in the revised legislative proposals on waste, including a common EU target for recycling $75 \%$ of packaging waste by 2030 (EC 2015b). To achieve higher recycling targets, lots of efforts have been put so far on the eco-efficiency concept, i.e. "making more with less", to reduce the GHG emissions in many metals using sectors, e.g. increasing the automotive (van Renssen 2011) and packaging waste collection (Rigamonti et al. 2010). However, in the case of aluminium according to Rombach (2013) "an increase in the efficiency of scrap collection has a significantly smaller impact on the relative availability of secondary raw materials than the growth in future demand for aluminium". At the same time, even though the globalization of postconsumer aluminium scrap market could allow greater GHG savings, e.g. under Spanish conditions (Sevigné-Itoiz et al. 2014), the export of post-consumer aluminium scrap is against the objectives of the circular economy. Companies in the beverage packaging sector were among the pioneers in the adoption of eco-efficiency based methodologies to reduce the environmental impacts of their products. They have gained an extensive experience in the implementation of Life Cycle Assessment (LCA) methodology (UNEP \& 
SETAC 2013). In the case of beer packaging, cans represented the second major packaging format (30\%) in 2012 at European level, and nearly half of all cans produced in the EU was destined for the brewing sector (Berkhout et al. 2013). LCA is widely used by the aluminium industry to assess its achievement in terms of environmental sustainability goals (Liu and Müller 2012), as well as to quantify the environmental performances of aluminium recycling (e.g. Paraskevas et al. 2015). Extensive work in the application of LCA for aluminium cans has been performed by both the aluminium industry (e.g. Stichling and NguyenNgoc 2009; EAA 2013), as well as by beer and packaging manufacturers companies, either for comparing the environmental performances of different packaging (Cordella et al. 2008; Detzel and Mönckert 2009) or to identify the hotspot in beer production (Talve 2001; Koroneos et al. 2005). The most effective solution for reducing the environmental impacts of beer packed in aluminium cans pointed by LCA studies is an increase in collection rate (Detzel and Mönckert 2009; Stichling and Nguyen-Ngoc 2009). The adoption of the LCA methodology to quantify the potential environmental impacts of a product system avoids burden shifting, both in terms of life cycle stages and among different impact categories (ISO 2006a, 2006b). Moreover, a reduction of packaging weight can be considered as a form of waste prevention activity, since less materials will have to be disposed at the end of life, and the environmental impacts deriving from the transport of lighter packaging (e.g. glass) are reduced (Nessi et al. 2013). However, increasing material efficiency represents only one driver for achieving a continuous flow of resources in circular material loops.

To implement the circular economy, a broader approach oriented towards product quality and innovation, i.e. the Cradle to $\mathrm{Cradle}^{\circledR}$ (hereafter $\mathrm{C} 2 \mathrm{C}$ ) design framework, can inspire companies in the beverage sector. The C2C vision, as one of the main conceptual pillars of the circular economy (CIRAIG 2015), defines a framework for designing products and industrial processes that turn materials into nutrients by enabling their perpetual flow within one of two distinct metabolisms: the biological metabolism and the technical metabolism (Braungart et al. 2007). C2C is oriented towards an increase of the positive footprint of products by designing "eco-effective" solutions, i.e. maximizing the benefit to ecological and economic systems, differently from the eco-efficiency approach, which instead aims to reduce the negative impacts of products, (Bjørn and Hauschild 2013). The C2C design framework is based on three key principles "waste equal food", "use current solar income" and "celebrate diversity" (McDonough and Braungart 2002). The first principle calls for eliminating the concept of waste by designing systems where waste and emissions can be taken up as nutrients by other processes instead of reducing the amount of waste as eco-efficiency advocates. Eco-effectiveness focuses on the development of products that maintain or enhance the quality and productivity of materials through subsequent life cycles (Braungart et al. 2007). One key aspect of the C2C design framework is the "up-cycling" concept, i.e. increasing the value of materials by improving the quality of recycling and recycled material. 
The differences in quality between the metal inputs and the produced secondary metals are usually not taken into account in conventional LCA studies. There are several types of losses connected with the recycling of metals, including aluminium (Castro et al. 2004; Amini et al. 2007; Nakamura et al. 2012; Paraskevas et al. 2015): (i) material losses, i.e. physical losses during scrap preparation and separating processes and melting losses; (ii) quality losses, i.e. due to mismatch between the composition of secondary material and input material requiring alloying elements to be added, and (iii) dilution losses, due to the dilution with primary aluminium to lower the concentration of contaminants to the desired limits of the target alloy. After analysing the influence of scrap quality on the environmental assessment of aluminium recycling, Paraskevas et al. (2015) concluded that container and packaging scrap can be perfectly managed in a separate closed loop recycling strategy for the same application. However, according to the European Aluminium Association (EAA), from an environmental point of view it doesn't matter whether used cans end up again in new cans or in other product systems (Labberton 2011). This statement leads to think that from an environmental perspective there is no preferred option for the next use of recycled aluminium. The Life Cycle Inventory (LCI) modelling of aluminium processes is traditionally based on a pure aluminium flow, therefore neglecting the presence of alloying elements and impurities (EAA 2013). This simplification can threaten the capability of LCA to objectively quantify the environmental performance of closed loop aluminium can recycling. The accumulation of impurities can indeed limit a continuous can-to-can recycling in the future, as demonstrated by Løvik and Mueller (2014). Increased recycling rates could potentially lead to an increase of the mass fraction of impurities in aluminium cans (Løvik and Mueller 2014), but the influence of alloying elements (e.g. $\mathrm{Si}, \mathrm{Cu}, \mathrm{Zn}, \mathrm{Mg}, \mathrm{Mn}$ ) accumulation on closed loop aluminium recycling has not yet been systematically assessed.

Therefore, the aim of this study is to answer the following Hamlet dilemma: "In the circular economy context is it better for aluminium cans to be or not to be in a closed product loop (can-to-can) from an LCA standpoint?" To answer this question we focused on including the effect of alloying elements on the LCA modelling of aluminium can recycling and structured the study in two parts. First, we performed a mass balance of the main alloying elements $(\mathrm{Mn}, \mathrm{Fe}, \mathrm{Si}, \mathrm{Cu})$ in aluminium can recycling at increasing levels of recycling rate. The analysis distinguished between different aluminium packaging scrap sources to understand the limiting factors for continuous aluminium recycling. Secondly, we performed an LCA of aluminium can production and recycling in multiple loops according to the different aluminium packaging scrap sources, to identify the best options from an environmental point of view.

\section{Methodology}

\subsection{Mass balance of alloying elements}


We considered the life cycle of an aluminium beverage can, and focused on the production and recycling stages. Aluminium cans are typically composed of two main parts, the body and the lid, made of two different wrought alloys. The body is an alloy from the 3xxx-series, either AA3004 or AA3104, with higher manganese content. Meanwhile, the lid is made from an alloy from the 5xxx-series (typically AA5182) with higher magnesium content (The University of Liverpool 2015). Some of the alloying elements, e.g. Fe and $\mathrm{Si}$, are already present in aluminium ores (EAA 2013). During can body and lid manufacturing the composition is adjusted to comply with the specific alloy requirements, as reported in Table 1.

Table 1: Threshold composition (as mass fraction) for alloying elements and $\mathrm{Al}$ in can body (3004 alloy), lid (5182 alloy), Used Beverage Can (UBC) scrap and mixed post-consumer aluminium packaging scrap.

\begin{tabular}{|c|c|c|c|c|c|c|c|c|c|c|c|}
\hline Alloy/scrap type & $\mathrm{Mg}$ & $\mathrm{Mn}$ & $\mathrm{Fe}$ & $\mathrm{Si}$ & $\mathrm{Cu}$ & $\mathrm{Zn}$ & $\mathrm{Cr}$ & $\mathrm{Ti}$ & $\begin{array}{c}\text { Other } \\
\text { Elements }\end{array}$ & $\begin{array}{l}\text { Total } \\
\text { Other }\end{array}$ & $\mathrm{Al}^{\mathrm{d}}$ \\
\hline $\begin{array}{l}3004^{\mathrm{a}} \\
\text { (Body) }\end{array}$ & $0.80 \%$ & $1.00 \%$ & $0.00 \%$ & $0.00 \%$ & $0.00 \%$ & $0.00 \%$ & - & - & $0.00 \%$ & $0.00 \%$ & $98.05 \%$ \\
\hline (Body) max & $1.30 \%$ & $1.50 \%$ & $0.70 \%$ & $0.30 \%$ & $0.25 \%$ & $0.25 \%$ & - & - & $0.05 \%$ & $0.15 \%$ & $95.55 \%$ \\
\hline $\begin{array}{l}5182^{\mathrm{a}} \\
(\mathrm{Lid})\end{array}$ & $4.00 \%$ & $0.20 \%$ & $0.00 \%$ & $0.00 \%$ & $0.00 \%$ & $0.00 \%$ & $0.00 \%-$ & $0.00 \%$ & $0.00 \%$ & $0.00 \%$ & $95.65 \%$ \\
\hline (Lid) $\max$ & $5.00 \%$ & $0.50 \%$ & $0.35 \%$ & $0.20 \%$ & $0.15 \%$ & $0.25 \%$ & $0.10 \%$ & $0.10 \%$ & $0.05 \%$ & $0.15 \%$ & $93.20 \%$ \\
\hline $\mathrm{UBC}_{\text {scrap }}^{\mathrm{b}}$ & $1.30 \%$ & $1.00 \%$ & $0.50 \%$ & $0.30 \%$ & $0.20 \%$ & $0.05 \%$ & - & $0.05 \%$ & $\leq 0.05 \%$ & $\leq 0.15 \%$ & $96.28 \%$ \\
\hline $\begin{array}{l}\text { Mixed Al } \\
\text { packaging } \\
\text { scrap }^{c}\end{array}$ & $0.20 \%$ & $0.40 \%$ & $1.00 \%$ & $1.00 \%$ & $2.50 \%$ & - & - & $0.10 \%$ & $\leq 0.10 \%$ & - & $94.70 \%$ \\
\hline
\end{tabular}

${ }^{\mathrm{a}}$ The University of Liverpool (2015)

${ }^{\mathrm{b}}$ EN 13920:2003 “Aluminium and aluminium alloys - Scrap" Part 10: scrap consisting of used aluminium beverage cans

${ }^{c}$ EN 13920:2003 “Aluminium and aluminium alloys - Scrap" Part 14: scrap from post-consumer aluminium packagings

${ }^{\mathrm{d}}$ Calculated by subtracting the cumulative alloying elements composition

The key actors involved in aluminium recycling are collectors and dismantlers, shredders and finally refiners and remelters (EAA 2006). Two different phases are involved in the recycling of packaging materials: selection and reprocessing. The selection phase depends on the packaging waste collection scheme, which can be of different types according to the market and regulation, i.e. kerbside vs drop-off, mono-material vs multi-material (Rigamonti et al. 2010). The reprocessing can be divided into further steps: shredding, decoating, melting and casting (Wang et al. 2007). First, during sorting and shredding, iron as well as nonferrous materials and coatings are separated by means of different techniques. UBC and packaging are further subject to delaquering and baling. There are titanium oxide, iron, titanium and aluminium silicates in the coating on the UBCs (Wang et al. 2007). This scrap can be de-coated by passing scrap through an oven or a mesh conveyer whilst hot gases are circulated through the mesh to volatilise or burn off the coating. De- 
coating is usually the only significant scrap preparation step which can be applied to the scrap input by the remelters (Leroy 2009). During remelting, only $\mathrm{Mg}$ and $\mathrm{Zn}$ can be removed to an appreciable extent, meanwhile $\mathrm{Si}, \mathrm{Cu}, \mathrm{Mn}, \mathrm{Fe}$ remain in the metal phase (Nakajima et al. 2010). The last step of aluminium recycling deals with alloy composition adjustment, where the amount of material lost in the previous steps of collection and pre-processing is added and the desired alloying element composition is reached through addition of virgin alloying materials or virgin/secondary aluminium according to the final alloy.

To perform a mass balance of the main alloying elements ( $\mathrm{Mn}, \mathrm{Fe}, \mathrm{Si}, \mathrm{Cu}, \mathrm{Cr}, \mathrm{Ti}, \mathrm{Zn}, \mathrm{Mg}$ ), we followed the approach proposed by Løvik and Mueller (2014), where the recycled material is used to produce new bodies. The mass balance of the main alloying elements was performed throughout can production and recycling, as reported in Fig. 1,assuming an ideal scenario, with no adjustment in the alloy composition, to understand the evolution of the mass fraction of the alloying elements over multiple loops.

We considered different scenarios for the recycling of aluminium beverage cans, which differ for the source of aluminium scrap: mixed aluminium packaging scrap, which includes not only UBC but also other types of aluminium packaging, such as menu trays, cups, tubes, capsules and closures, are used as source, named Mixed Aluminium Packaging (MAP scenario) and UBC scrap, therefore UBC scenario . Further scenario variables considered were: EoL recycling rate $(\mathrm{RR})$, yield during pre-processing ( $\left.\mathrm{Y}_{\text {pre-proc }}\right)$ and remelting ( $\mathrm{Y}_{\text {remelt }}$ ), and the recycled content (RC). A summary of the scenarios analysed is reported in Table 2, which further includes the parameters considered to perform the mass balance, as well as a definition of the main EoL metrics considered, according to Rombach (2013) and Løvik and Mueller (2014).

Table 2: Summary of the end-of-life metrics considered in the two scenarios compared, representative of closed product category loop (MAP scenario), and closed product loop (UBC scenario), respectively. Metrics are defined according to Rombach (2013) and Løvik and Mueller (2014).

\begin{tabular}{|c|c|c|c|c|}
\hline Metric & Acronym & Definition & $\begin{array}{c}\text { MAP } \\
\text { scenario }\end{array}$ & $\begin{array}{c}\text { UBC } \\
\text { scenario }\end{array}$ \\
\hline $\begin{array}{l}\text { End-of-life } \\
\text { Recycling } \\
\text { Rate }\end{array}$ & $\mathrm{RR}$ & $\begin{array}{l}\text { Recycled aluminium produced from } \\
\text { old scrap / aluminium available from } \\
\text { old scrap sources (Rombach 2013) }\end{array}$ & $\begin{array}{l}55.0 \% \\
65.0 \% \\
75.0 \%\end{array}$ & $\begin{array}{l}55.0 \% \\
65.0 \% \\
75.0 \%\end{array}$ \\
\hline $\begin{array}{l}\text { Pre-processing } \\
\text { Yield }\end{array}$ & $Y_{\text {pre-proc }}$ & $\begin{array}{l}\text { Material entering pre-processing / } \\
\text { material available after pre-processing } \\
\text { (Løvik and Mueller 2014) }\end{array}$ & $\begin{array}{l}99.0 \% \\
\text { (PE Americas } \\
\text { 2010) }\end{array}$ & $\begin{array}{l}99.0 \% \\
\text { (PE Americas } \\
\text { 2010) }\end{array}$ \\
\hline $\begin{array}{l}\text { Remelting } \\
\text { Yield }\end{array}$ & $\mathrm{Y}_{\text {remelt }}$ & $\begin{array}{l}\text { Material entering remelting / material } \\
\text { available after remelting (Løvik and } \\
\text { Mueller 2014) }\end{array}$ & $\begin{array}{c}95.0 \% \\
\text { (Leroy 2009) }\end{array}$ & $\begin{array}{c}97.5 \% \\
\text { (Leroy 2009) }\end{array}$ \\
\hline $\begin{array}{l}\text { Collection } \\
\text { Rate }\end{array}$ & $\mathrm{CR}$ & $R R \cdot Y_{\text {pre-proc }} \cdot Y_{\text {remelt }}$ & $\begin{array}{l}60.3 \% \\
71.2 \% \\
82.2 \%\end{array}$ & $\begin{array}{l}57.0 \% \\
67.3 \% \\
77.7 \%\end{array}$ \\
\hline
\end{tabular}


We considered that lid is produced from virgin raw material, meanwhile aluminium scrap is used to produce new can body (Gaustad et al. 2007; Nakajima et al. 2010). We included only recycling of post-consumer scrap, representing the largest amount of scrap produced. Furthermore, pre-consumer scrap originating during the fabrication of semi-finished products are usually retained in the manufacturing process itself and do not enter the scrap market (Rombach 2013). The model considers that a new can is produced out of aluminium scrap after 60 days (Løvik and Mueller 2014). We simulated an interval of 5 years, which corresponds to 30 recycling loops. Collection rates (CR) were calculated, starting from the value of RR, $\mathrm{Y}_{\text {pre- }}$ proc and $Y_{\text {remelt, }}$ which change according to the type of scrap used, as reported in Table 2. We neglected the influence of the type of collection, therefore the model can be considered to be not country-specific. Different values for the RR were considered reflecting UK market: 55\%, i.e. the recycling rate in year 2009 (EAA 2010), 65\%, i.e. the current recycling rate (EAA 2015) and 75\%, i.e. the target set by the EAA for 2015 (Alupro 2015). We performed a mass balance for Al and all main alloying elements, for 30 loops, assuming that for every loop the material reintegrated during the "alloy adjustment" stage is mixed with the remelted aluminium to provide new can body, but focus here on $\mathrm{Mn}, \mathrm{Si}, \mathrm{Fe}, \mathrm{Cu}$, i.e. the alloying elements remaining in the metal phase after remelting (Nakajima et al. 2010). The composition of the reintegrated material flow changes according to the type of scrap used (see Table 1), i.e. post-consumer aluminium packaging scrap (MAP scenario) and UBC scrap (UBC scenario). We considered the maximum threshold values allowed in the European standard EN 13920:2003 for scrap consisting of used aluminium beverage cans and scrap from post-consumer aluminium packaging, respectively. The mean or expected composition values reported in literature (Hatayama et al. 2012) refer to "container and packaging" flow, whose composition is similar with the composition of UBC reported in Table 1.

\subsection{Life Cycle Assessment}

In a previous LCA conducted following the conventional pure Al flow modelling (Niero et al. 2016), LCA proved to be able to quantify the environmental impacts of a $33 \mathrm{cl}$ aluminium can for the UK market, comparing different scenarios, where the recycled content (\% RC) and the \% of renewable energy (RE) were changed. We focused here on one scenario (i.e. $0 \% \mathrm{RE}, 65 \% \mathrm{RC}$ ) and used the same input data to perform an LCA including the results of the mass balance of alloying elements presented in section 2.1. We followed the requirements of the ISO 14040-44 standards (ISO 2006a, 2006b) and ILCD Handbook (EC-JRC-IES 2011).

\subsubsection{Goal and scope definition}


The goal of the comparative LCA is to compare the potential environmental impacts for different sources of Al packaging scrap used in can production. One of the features of the circular economy is to use materials in continuous loops, therefore the function (and functional unit, FU) of the product system should be defined accordingly. In the conventional pure Al flow LCA modelling, the FU for beer cans is usually "the containment of a certain amount of beer until the expiry date", typically $1 \mathrm{hl}$ (Detzel and Mönckert 2009; IEC 2014). In the circular economy perspective the function of the can is not only to carry (and protect) its content, but also provide the aluminium scrap as secondary resource for subsequent product systems. Therefore in this study we defined a different FU called "Circular economy-inspired FU" as "the containment of $1 \mathrm{hl}$ of beer until the expiry date and supply of resource after its use stage for 30 loops". The idea of multiple co-functions is introduced in the ILCD Handbook, Annex C (EC-JRC-IES 2011). However, to properly model the continuous flow of materials, it is necessary to shift the focus from a pure Al flow to modelling the actual alloy composition, i.e. including the production and change in composition of the alloying elements. Therefore, we conducted an LCA considering the actual alloy composition of both the lid and the can body, as reported in Table 1. A first attempt to perform LCA of aluminium alloys has been presented by Paraskevas et al. (2015) for the major post-consumer scrap streams, but we here further differentiate between the components of the can. Apart from the can body and lid manufacturing, the actual can production including lacquering, filling of the can, and then the recycling with pre-processing, remelting and alloy adjustment stages, are included in the system boundaries presented in Fig. 1. Excluded from the system boundaries are the distribution system of the can, its use, as well as all the transports of raw materials from suppliers and waste scrap to the EoL treatment. According to previous LCAs on aluminium cans (Stichling and Nguyen-Ngoc 2009; Niero et al. 2016), the contribution of the raw materials and final product transport to the overall environmental impacts can be considered negligible in comparison to the impact from primary aluminium. Concerning the EoL of the can, we choose to apply the EoL equation provided by the Product Environmental Footprint (PEF) guide (EC 2013), since this method was considered the most suitable for considering the multiple uses of resources in continuous loops (Allacker et al. 2014). In the EoL equation we assumed a value for the RC equal to 67.8\% (PE Americas 2010), kept constant over the 30 loops modelled, where RC is defined as the amount of secondary aluminium over the amount of aluminium from primary and secondary sources (Rombach 2013).

\subsubsection{Life Cycle Inventory}

We modelled 30 cycles of production and recycling of aluminium cans, according to the scheme reported in Fig. 2, which includes five life cycle stages, i.e. lid production, can body production, can manufacturing and filling, end-of-life (i.e. disposal and recycling), and material reintegration.

According to the ILCD Handbook, Annex C (EC-JRC-IES 2011), to provide the first co-function, i.e. the containment of $1 \mathrm{hl}$ of beer, the can has to be produced, meanwhile to provide the second function, i.e. the 
supply of resource, it is sufficient if the aluminium grade the can is made of is produced, while all other steps, e.g. transporting the aluminium to the can plant, making the can, are not attributable to the provision of the scrap. In the first loop $(n=0)$, both the lid and the can body are manufactured from primary aluminium and virgin alloying elements, including $\mathrm{Mn}, \mathrm{Fe}, \mathrm{Si}, \mathrm{Cu}, \mathrm{Cr}, \mathrm{Ti}, \mathrm{Zn}, \mathrm{Mg}$, according to the specific alloy composition (see Table 3). Meanwhile, in the following loops (from $n=1$ to $n=29$ ) the body production originates from the combination of recycled material from previous loop and the amount of material (either virgin materials or post-consumer packaging scrap) that needs to be reintegrated to close the mass balance. The composition of the reintegrated material changes according to the scrap source and the \%RR. The main input and output considered for each life cycle stages are also reported in Fig. 2a, for loop $n=0$ and Fig. 2b for loop $n=1$ to 29 . The new can body flow for $n=[1,29]$ is given by the sum of the specific material reintegration stage and the material recycled during the previous life cycle, as shown in Fig. 2. The multiple product system modelling was performed with Simapro v8.0.4.30 (PRé 2013) and the database used to model the LCI was ecoinvent v3.1 (Moreno Ruiz et al. 2014).

Table 3 Life cycle inventory flows for the life cycle stages of loop $n=0$ of the aluminium can production and recycling. For each life cycle stage the reference flow, the list of input $(I)$ and output $(O)$, the dataset used, as well as the considered amount (either a parameter or a value) and unit are reported. Names in italics refer to the ecoinvent process used.

\begin{tabular}{|c|c|c|c|c|}
\hline $\begin{array}{l}\text { Life Cycle } \\
\text { Stage }\end{array}$ & $\begin{array}{l}\text { Input (I) / } \\
\text { Output (O) }\end{array}$ & Dataset & Amount & Unit \\
\hline \multirow{13}{*}{$\begin{array}{l}\text { Lid } \\
\text { production }\end{array}$} & Primary Al (I) & $\begin{array}{l}\text { Aluminium, primary, ingot }\{U N-E U R O P E\} \mid \\
\text { production }\end{array}$ & $\operatorname{mass}_{\text {lid }} C_{A l \_l i d}$ & $\mathrm{~kg}$ \\
\hline & Sheet rolling (I) & Sheet rolling, aluminium $\{R E R\} \mid$ processing & mass $_{\text {lid }}$ & $\mathrm{kg}$ \\
\hline & $\operatorname{Mn}(\mathrm{I})$ & Manganese $\{R E R\} \mid$ production & mass $_{\text {lid }} \cdot C_{M n \_l i d}$ & $\mathrm{~kg}$ \\
\hline & $\mathrm{Fe}(\mathrm{I})$ & Pig iron $\{G L O\} \mid$ production & mass $_{\text {lid }} C_{\mathrm{Fe}_{-} \text {lid }}$ & $\mathrm{kg}$ \\
\hline & $\mathrm{Si}(\mathrm{I})$ & $\begin{array}{l}\text { Silicon, metallurgical grade }\{\text { RoW }\} \mid \\
\text { production }\end{array}$ & $\operatorname{mass}_{\text {lid }} C_{S i_{-} l i d}$ & $\mathrm{~kg}$ \\
\hline & $\mathrm{Cu}(\mathrm{I})$ & Copper $\{R E R\} \mid$ production, primary & mass $_{\text {lid }} C_{\text {Cu_lid }}$ & $\mathrm{kg}$ \\
\hline & $\mathrm{Cr}(\mathrm{I})$ & Chromium $\{R E R\} \mid$ production & mass $_{l i d} \cdot C_{C_{-} \_l i d}$ & $\mathrm{~kg}$ \\
\hline & $\operatorname{Ti}(\mathrm{I})$ & $\begin{array}{l}\text { Titanium dioxide }\{R E R\} \mid \text { production, } \\
\text { chloride process }\end{array}$ & $\operatorname{mass}_{\text {lid }} C_{T i_{\_} l i d}$ & $\mathrm{~kg}$ \\
\hline & $\mathrm{Zn}(\mathrm{I})$ & $\begin{array}{l}\text { Zinc }\{G L O\} \mid \text { primary production from } \\
\text { concentrate }\end{array}$ & $\operatorname{mass}_{\text {lid }} \cdot C_{Z n_{-} \_l i d}$ & $\mathrm{~kg}$ \\
\hline & $\operatorname{Mg}(\mathrm{I})$ & $\begin{array}{l}\text { Magnesium }\{\text { RoW }\} \mid \text { magnesium production, } \\
\text { electrolysis }\end{array}$ & mass lid $_{\text {lid }} C_{\text {Mg_lid }}$ & $\mathrm{kg}$ \\
\hline & Electricity(I) & $\begin{array}{l}\text { Electricity, high voltage, aluminium industry } \\
\{\text { UN-EUROPE\}| electricity production, } \\
\text { hydro, aluminium industry }\end{array}$ & $0.81^{\mathrm{a}}$ & MJ \\
\hline & Heat (I) & $\begin{array}{l}\text { Heat, central or small-scale, other than } \\
\text { natural gas }\{C H\} \mid \text { heat production, light fuel } \\
\text { oil, at boiler } 100 \mathrm{~kW} \text {, non-modulating }\end{array}$ & $6.66^{\mathrm{a}}$ & MJ \\
\hline & Lid $(\mathrm{O})$ & - & mass $_{\text {lid }}$ & $\mathrm{kg}$ \\
\hline Body & Primary $\mathrm{Al}(\mathrm{I})$ & Aluminium, primary, ingot $\{U N-E U R O P E\} \mid$ & $(1-R C / 2)$ & $\mathrm{kg}$ \\
\hline
\end{tabular}




\begin{tabular}{|c|c|c|c|c|}
\hline \multirow[t]{13}{*}{ production } & & production & $\operatorname{mass}_{\text {body }} \cdot C_{A l \_b o d y}$ & \\
\hline & $\begin{array}{l}\text { Secondary Al } \\
\text { (I) }\end{array}$ & $\begin{array}{l}\text { Aluminium scrap, post-consumer, prepared } \\
\text { for melting }\{R E R\} \mid \text { treatment of aluminium } \\
\text { scrap, post-consumer, by collecting, sorting, } \\
\text { cleaning, pressing }\end{array}$ & $\begin{array}{c}R C / 2 \cdot \\
\operatorname{mass}_{\text {body }} \cdot C_{A l \_b o d y}\end{array}$ & $\mathrm{~kg}$ \\
\hline & Sheet rolling $(\mathrm{I})$ & Sheet rolling, aluminium $\{R E R\} \mid$ processing & mass $_{\text {body }}$ & $\mathrm{kg}$ \\
\hline & $\mathrm{Mn}(\mathrm{I})$ & Manganese $\{R E R\} \mid$ production & $\operatorname{mass}_{\text {body }} \cdot C_{\text {Mn_body }}$ & $\mathrm{kg}$ \\
\hline & $\mathrm{Fe}(\mathrm{I})$ & Pig iron $\{G L O\} \mid$ production & $\operatorname{mass}_{\text {bodv }} \cdot C_{F e \_b o d y}$ & $\mathrm{~kg}$ \\
\hline & $\mathrm{Si}(\mathrm{I})$ & $\begin{array}{l}\text { Silicon, metallurgical grade }\{\text { RoW }\} \mid \\
\text { production }\end{array}$ & mass $_{\text {body }} \cdot C_{S i \_b o d y}$ & $\mathrm{~kg}$ \\
\hline & $\mathrm{Cu}(\mathrm{I})$ & Copper $\{R E R\} \mid$ production, primary & $\operatorname{mass}_{\text {body }} \cdot C_{C u \_b o d y}$ & $\mathrm{~kg}$ \\
\hline & $\mathrm{Zn}(\mathrm{I})$ & $\begin{array}{l}\text { Zinc }\{G L O\} \mid \text { primary production from } \\
\text { concentrate }\end{array}$ & $\operatorname{mass}_{\text {body }} \cdot C_{Z n \_b o d y}$ & $\mathrm{~kg}$ \\
\hline & $\operatorname{Mg}(\mathrm{I})$ & $\begin{array}{l}\text { Magnesium }\{\text { RoW }\} \mid \text { magnesium production, } \\
\text { electrolysis }\end{array}$ & $\operatorname{mass}_{\text {body }} \cdot C_{M g_{-} b o d y}$ & $\mathrm{~kg}$ \\
\hline & Electricity(I) & $\begin{array}{l}\text { Electricity, high voltage, aluminium industry } \\
\{U N-E U R O P E\} \mid \text { electricity production, } \\
\text { hydro, aluminium industry }\end{array}$ & $12.79^{\mathrm{a}}$ & MJ \\
\hline & Heat (I) & $\begin{array}{l}\text { Heat, central or small-scale, other than } \\
\text { natural gas }\{\mathrm{CH}\} \mid \text { heat production, light fuel } \\
\text { oil, at boiler } 100 \mathrm{~kW} \text {, non-modulating }\end{array}$ & $128.50^{\mathrm{a}}$ & MJ \\
\hline & Body $(\mathrm{O})$ & - & mass $_{b o d y}$ & $\mathrm{~kg}$ \\
\hline & $\begin{array}{l}\text { Al to landfill } \\
(\mathrm{O})\end{array}$ & $\begin{array}{l}\text { Waste aluminium }\{\mathrm{CH}\} \mid \text { treatment of, } \\
\text { sanitary landfill }\end{array}$ & $-\mathrm{RC} / 2 \cdot$ mass $_{\text {body }}$ & $\mathrm{kg}$ \\
\hline \multirow{8}{*}{$\begin{array}{l}\text { Can } \\
\text { manufa- } \\
\text { cturing \& } \\
\text { filling }\end{array}$} & Lid (I) & Lid production & mass $_{\text {lid }}$ & $\mathrm{kg}$ \\
\hline & Body (I) & Body production & mass $_{\text {body }}$ & $\mathrm{kg}$ \\
\hline & \multirow{3}{*}{ Lacquer (I) } & Epoxy resin, liquid $\{R E R\} \mid$ production & $0.026^{b}$ & $\mathrm{~kg}$ \\
\hline & & $\begin{array}{l}\text { Polyester resin, unsaturated }\{R E R\} \mid \\
\text { production }\end{array}$ & $0.052^{\mathrm{b}}$ & $\mathrm{kg}$ \\
\hline & & $\begin{array}{l}\text { Acrylic varnish, without water, in } 87.5 \% \\
\text { solution state }\{\text { RER } \mid \text { acrylic varnish } \\
\text { production, product in } 87.5 \% \text { solution state }\end{array}$ & $0.052^{\mathrm{b}}$ & $\mathrm{kg}$ \\
\hline & Electricity(I) & $\begin{array}{l}\text { Electricity, high voltage, aluminium industry } \\
\{U N-E U R O P E\} \mid \text { electricity production, } \\
\text { hydro, aluminium industry }\end{array}$ & 1.06 & $\mathrm{kWh}$ \\
\hline & Heat (I) & $\begin{array}{l}\text { Heat, district or industrial, natural gas } \\
\text { \{Europe without Switzerland } \mid \text { heat } \\
\text { production, natural gas, at industrial } \\
\text { furnace }>100 \mathrm{~kW}\end{array}$ & 1.33 & $\mathrm{kWh}$ \\
\hline & Filled can $(\mathrm{O})$ & - & mass $_{\text {can }}+$ mass $_{\text {paint }}$ & $\mathrm{kg}$ \\
\hline \multirow{7}{*}{ End-of-life } & Filled can $(\mathrm{I})$ & - & mass $_{\text {can }}+$ mass $_{\text {paint }}$ & $\mathrm{kg}$ \\
\hline & Recycled can & - & $\begin{array}{l}R R \cdot\left(\text { mass }_{\text {can }}+\right. \\
\text { mass } \text { paint })\end{array}$ & $\mathrm{kg}$ \\
\hline & Primary Al (O) & $\begin{array}{l}\text { Aluminium, primary, ingot }\{U N-E U R O P E\} \mid \\
\text { production }\end{array}$ & $\begin{array}{c}-R R / 2 \cdot \\
\left(\operatorname{mass}_{l i d} \cdot C_{A l \_l i d}+\right. \\
\left.\operatorname{mass}_{\text {body }} \cdot C_{A l \_b o d y}\right)\end{array}$ & $\mathrm{kg}$ \\
\hline & $\operatorname{Mn}(\mathrm{O})$ & Manganese $\{R E R\} \mid$ production & $\begin{array}{c}-R R / 2 \cdot \\
\left(\operatorname{mass}_{l i d} \cdot C_{M n \_l i d}+\right. \\
\left.\operatorname{mass}_{\text {bodv }} \cdot C_{M n \_b o d v}\right) \\
\end{array}$ & $\mathrm{kg}$ \\
\hline & $\mathrm{Fe}(\mathrm{O})$ & Pig iron $\{G L O\} \mid$ production & $\begin{array}{c}-R R / 2 \cdot \\
\left(\operatorname{mass}_{\text {lid }} \cdot C_{F e_{-} l i d}+\right. \\
\left.\operatorname{mass}_{\text {body }} \cdot C_{F e \_b o d y}\right)\end{array}$ & $\mathrm{kg}$ \\
\hline & $\mathrm{Si}(\mathrm{O})$ & $\begin{array}{l}\text { Silicon, metallurgical grade }\{\text { RoW }\} \mid \\
\text { production }\end{array}$ & $\begin{array}{c}-R R / 2 \cdot \\
\left(\operatorname{mass}_{\text {lid }} \cdot C_{S i \_l i d}+\right. \\
\left.\operatorname{mass}_{\text {body }} \cdot C_{S i \_b o d y}\right)\end{array}$ & $\mathrm{kg}$ \\
\hline & $\mathrm{Cu}(\mathrm{O})$ & Copper $\{R E R\} \mid$ production, primary & $\begin{array}{c}-R R / 2 \cdot \\
\left(\operatorname{mass}_{\text {lid }} C_{C u \_l i d}+\right.\end{array}$ & $\mathrm{kg}$ \\
\hline
\end{tabular}




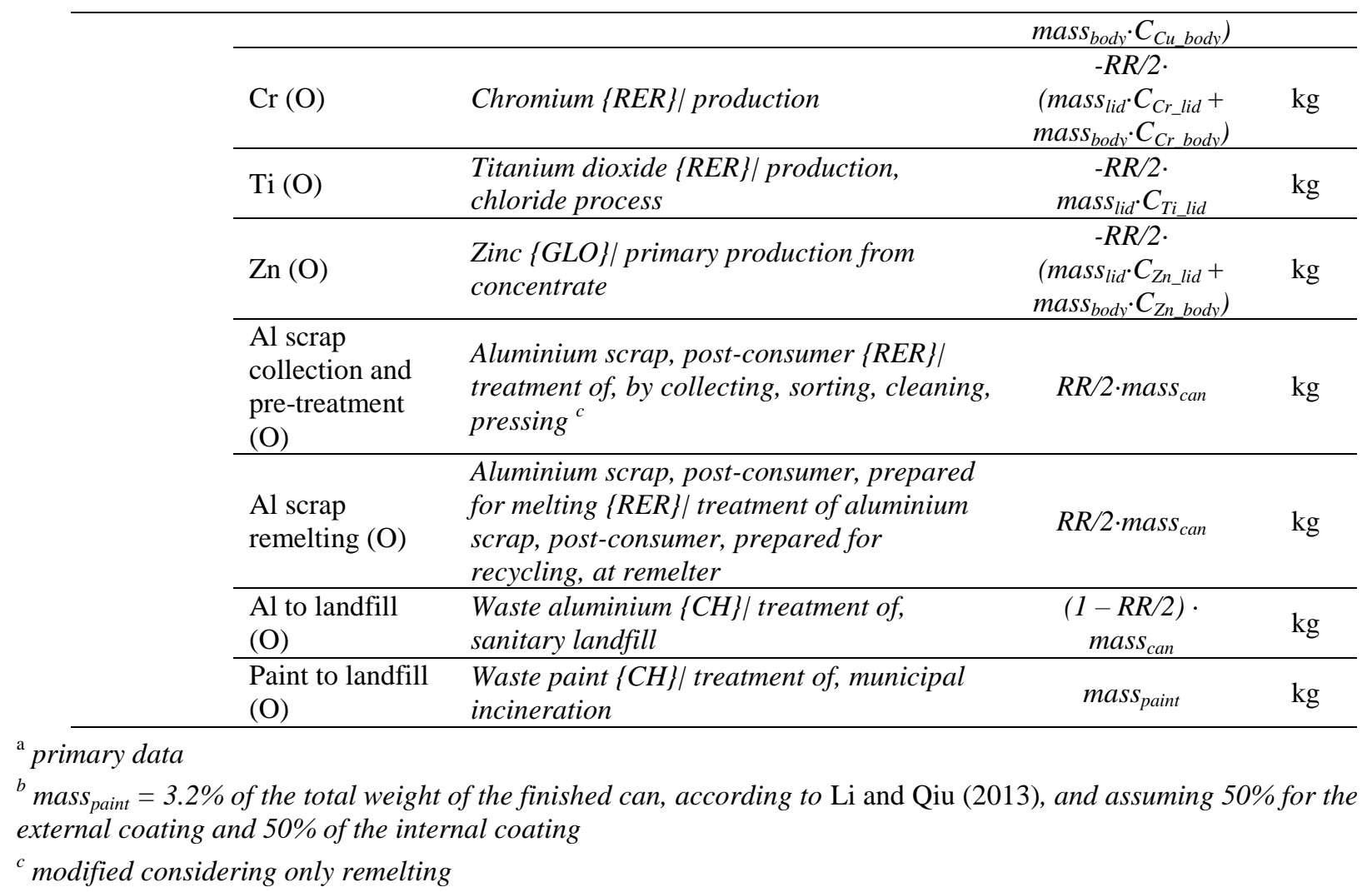

The data used, i.e. the weight of lid and body, and electricity and heat consumption during filling are mainly primary data for the UK market provided by the case study company. The EoL scenario refers to the UK situation, where packaging is collected as part of a mixed collection (ERM 2008). We considered the main disposal options, i.e. recycling and landfill, so disregarding that a negligible fraction goes to incineration. However, it has been proven that the contribution from the EoL of the cans both to landfill and incineration can be neglected, since it is less than $1 \%$, i.e. below the generally accepted cut-off level (Stichling and Nguyen-Ngoc 2009).

\subsubsection{Life Cycle Impact Assessment}

We followed the recommendations provided by the European Commission's Joint Research Center (Hauschild et al. 2013) and chose the ILCD recommended Life Cycle Impact Assessment (LCIA) method. We considered the LCIA both at characterization and normalization level and focused the interpretation on a selection of the most contributing impact categories, as shown in the results. The choice of the life cycle impact categories to be displayed was based on the normalized LCIA results, as performed by Niero et al. (2015b). 


\subsubsection{Sensitivity analyses}

Different techniques are used in the life cycle interpretation step to test the robustness of the outcomes of an LCA study, i.e. contribution, sensitivity and uncertainty analyses. We performed sensitivity analyses both at LCI and LCIA levels, as well as on the mass balance of the alloying elements. With regard to the last, we tested the following variables on the UBC option, which represents a closed product loop scenario (can-tocan recycling):

- Influence of can weight reduction (-6.3\%), considering a decrease of alternatively lid or can body weight, for the current \%RR;

- Influence of a potential separation of the lid and body can at the collection point, for $\mathrm{RR}=75 \%$ and considering the average of the top three higher beverage can RR at the EU level for the country adopting a deposit system, i.e. Finland (97\%), Norway (96\%) and Sweden (92\%) (EAA 2015), which provides a value of $95 \%$.

Within the LCA, we simulated the influence of the collection system on the overall environmental performances, i.e. assuming a different pace of increase of \%RR in the case of the MAP and UBC scenarios. For the MAP scenario, we calculated the $\%$ of increase based on the historical trend of increase for UK, considering that in the period $2009(\mathrm{RR}=55 \%)-2012(\mathrm{RR}=65 \%)$ the pace of yearly increase was $2.5 \%$. This case can exemplify a situation where the collection system remains unchanged in the future. Meanwhile, we simulated a case where the collection system shifts from the current kerbside system to a deposit system, where cans are separately collected, therefore simulating a closed product loop system. In general, deposit systems allow to achieve high collection rates of used packaging (Labberton 2011), therefore we assumed that if a deposit system was introduced in the UK market, then the \%RR in 5 years could reach the average RR of EU deposit systems, i.e. 85\% (considering 70-90\% provided by Alupro and 85-95\% by Eunomia Hogg et al. 2015) for Scotland. In this case the pace of yearly increase would be 5\%.

To assess the influence of data variability on the LCA results we performed parameter uncertainty analysis using a 1000-run Monte Carlo analysis (Frischknecht et al. 2007), considering the default probability distribution included in the ecoinvent v3.1 database (Ciroth et al. 2013).

To test the influence of the selection of the impact assessment method, we performed the LCIA using different LCIA methodologies. We particularly investigated the resource depletion impact category, since this category is very relevant in the discussion on resource scarcity (Klinglmair et al. 2013) and therefore circular economy. We chose two further LCIA methods, providing a different perspective towards abiotic resource depletion (Rørbech et al. 2014), namely a resource accounting method, i.e. Cumulative Exergy Demand, CexD, (in terms of MJ) (Bösch et al. 2007), and an ore grade quality method, i.e. ReCiPe 2008+ at endpoint level (in terms of \$) (Goedkoop et al. 2009), to be compared with the use-to availability method 


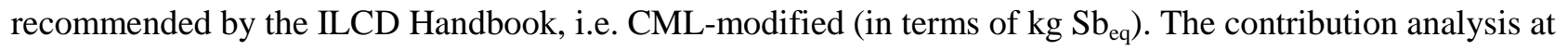
the process level allowed to identify the hot spots in term of most relevant resources for each method considered, therefore informing about the uncertainty at the LCIA level. We further tested the human toxicity impact category which, compared to other impact categories in LCI, is affected by higher variability among the characterization models (Hauschild et al. 2008).

\section{Results}

\subsection{Variation of alloying elements in can body}

The mass balance of the main alloying elements, during can production and recycling, assuming an ideal closed loop system over 30 loops is displayed in Fig. 3, for a) Mn, b) Fe, c) Si, d) Cu, respectively. Fig. 3 includes the variation of the mass fraction of the four alloying elements in can body according to the two alternative scenarios and the three sets of $\% \mathrm{RR}$, assuming that no adjustment in the alloy composition take place (ideal scenario). This theoretical exercise allows to identify the limiting alloying element as a function of the scrap source.

From Fig. 3a it emerges that in all cases adjustments on Mn composition are needed to stay within the threshold. The trend presented refers to an ideal case of no alloy composition adjustment, showing that depending on the \%RR a steady state composition is reached. For Fe (Fig. 3b) in a hypothetical 30 closed loops recycling, concentration adjustment would be needed only at RR=55\% for MAP scrap. For Si (Fig. 3c) the maximum threshold $(0.3 \%)$ would be respected only in the UBC scenarios. For $\mathrm{Cu}$ (Fig. 3c) the threshold $(0.25 \%)$ would be respected in all UBC scenarios, but not in the MAP scenarios. Different conclusions can be drawn according to the scenarios analysed: for UBC scenarios the limiting alloying elements for can body recycling is Mn. For MAP scenarios, primary aluminium needs to be added to dilute $\mathrm{Cu}$, in order to stay within the threshold. Moreover, a further requirement is needed for the MAP scrap fraction, whose $\mathrm{Cu}$ composition cannot be higher that $0.8 \%$, otherwise it is not possible to use this scrap in multiple loops. The necessary amount of Mn and primary Al to be reintegrated was calculated in order to stay within can body threshold for each loop $n=[1: 29]$. The composition of the material reintegration flow as a function of $\% \mathrm{RR}$ and scrap type is reported in Table 4 . These values have been used to feed the LCI model for $n=[1: 29]$, see section 3.2. 
Table 4 Composition of the material reintegration flow, according to the $\% R R$ and scrap type used. The remaining \% is given by the scrap, respectively Mixed Aluminium Packaging (MAP) scrap and Used Beverage Can (UBC) scrap.

\begin{tabular}{lcccccc}
\hline \multirow{2}{*}{ Scenario } & \multicolumn{2}{c}{$\mathbf{R R}=\mathbf{5 5 \%}$} & \multicolumn{2}{c}{$\mathbf{R R}=\mathbf{6 5 \%}$} & \multicolumn{2}{c}{$\mathbf{R R}=\mathbf{7 5 \%}$} \\
& $\mathbf{\%} \mathbf{M n}$ & $\mathbf{\%}$ Primary Al & \% Mn & $\begin{array}{c}\text { \% Primary } \\
\text { Al }\end{array}$ & \% Mn & $\begin{array}{c}\text { \% Primary } \\
\text { Al }\end{array}$ \\
\hline MAP & $1.200 \%$ & $80 \%$ & $1.400 \%$ & $80 \%$ & $2.500 \%$ & $80 \%$ \\
UBC & $0.140 \%$ & $0 \%$ & $0.375 \%$ & $0 \%$ & $1.750 \%$ & $0 \%$ \\
\hline
\end{tabular}

The results of the sensitivity analyses on the mass balance for Mn mass fraction in the UBC scenarios are reported in Fig. 4. For RR=65\%, a decrease of can weight obtained through body weight reduction has worse effects in terms of compliance with Mn concentration limits compared to a reduction in lid weight. Despite both cases fall outside the limits for Mn concentration, the reduction of lid weight can be considered within the $10 \%$ uncertainty range allowed by Paraskevas et al. (2015). The benefit of a reduction of can weight in terms of improvements of LCA results has been proven in the case of aluminium can (Detzel and Mönckert 2009). Moreover, a separation of body and lid at the collection point would positively affect the continuous can-to-can recycling, with body and lid recycling in separate cycles without Mn reintegration, even at higher RR (75\% and 95\%), see Fig. 4. Since UBCs are used in the production of can body, a can-to-can recycling is currently limited by the mass share of the body (Løvik and Mueller 2014), i.e. 79\% in the case of 33cl cans considered in the study.

\subsection{LCA results}

The normalized LCIA results at midpoint level according to the ILCD 2011 midpoint v1.05 (EU27, 2010, equal weighting) are reported in Fig. 5a at the current RR (65\%) for the two alternative scenarios (MAP and UBC). The most significant impact categories according to the ILCD 2011 midpoint are: human toxicity (cancer and non cancer effects), mineral, fossil and renewable resources depletion, climate change, particulate matter, and acidification. Meanwhile, Fig. $5 \mathrm{~b}$ reports the normalized LCIA results according to ReCiPe endpoint H/A world v1.11 for the same scenarios. The most significant impact categories are: fossil depletion, mineral depletion, climate change (both with contribution to human health and ecosystems), particulate matter formation and human toxicity. Since there is a correlation between climate change, particulate matter formation and acidification, when the drivers for the impact is energy consumption (Laurent et al. 2010), we will report only climate change hereafter.

The main differences for climate change impacts are due to the inclusion of primary aluminium in the reintegrated materials for MAP scenarios, where $\mathrm{Cu}$ concentration needs to be diluted. The same holds for 
fossil depletion (Fig. 5b), meanwhile for metal depletion the slightly lower value for UBC is due to the lower mass of Mn reintegrated. For human toxicity, both cancer and non cancer effects (Fig. 5a) the ranking in the impacts is correlated with the amount of primary aluminium reintegrated, and specifically to the treatment of red mud in residual material landfill from bauxite digestion.

The contribution analysis at process level with 1\% cut-off for resource depletion is displayed in Fig. 6 for the different LCIA tested, i.e. the ILCD recommended, ReCiPe at endpoint level and CexD. The contribution of the different unit processes is different according to the LCIA methods used: for ILCD the most contributing process is the extraction of $\mathrm{Zn}$, which is used as alloying elements in body lid and body production. No contribution to the overall impact is due to the energy-related processes, which are instead dominating for ReCiPe and CexD, namely natural gas, petroleum and hard coal used for primary aluminium production.

Fig. 7 summarizes the LCIA of the selected most relevant impact categories (ILCD recommended) including the uncertainty range: climate change (Fig. 7a), mineral, fossil \& renewable resource depletion (Fig 7b), human toxicity, both cancer (Fig 7c) and non- cancer effects (Fig. 7d) for all scenarios considered.

The results of the sensitivity analysis on the UBC collection system on the potential future environmental impacts in the case of mixed aluminium scrap (MAP assuming 75\% RR) and can-to-can recycling (UBC, assuming $85 \% \mathrm{RR}$ ) are reported in Table 5, where the LCIA score per ton of can body are reported.

\section{Table 5: LCIA results according to the ILCD recommended method for the significant LCIA} categories referred to 1 ton of new body can produced out of mixed aluminium packaging scrap (MAP scenario) and used beverage can scrap (UBC scenario, i.e. can-to-can recycling), assuming different pace of increase of the RR, i.e. $75 \%$ and $85 \%$, respectively.

\begin{tabular}{llcc}
\hline LCIA category & Unit & $\begin{array}{c}\text { MAP scenario } \\
(\mathbf{R R = 7 5 \% )}\end{array}$ & $\begin{array}{c}\text { UBC scenario } \\
(\mathbf{R R = 8 5 \%})\end{array}$ \\
\hline Climate change & $\mathrm{kgCO}_{2 \mathrm{eq}}$ & $1.29 \mathrm{E}+4$ & $9.57 \mathrm{E}+3$ \\
Mineral, fossil and renewable resources depletion & $\mathrm{kg} \mathrm{Sb}_{\mathrm{eq}}$ & $8.74 \mathrm{E}-1$ & $6.82 \mathrm{E}-1$ \\
Human toxicity, cancer effects & CTUh & $5.59 \mathrm{E}-4$ & $2.91 \mathrm{E}-4$ \\
Human toxicity, non-cancer effects & CTUh & $1.83 \mathrm{E}-3$ & $1.24 \mathrm{E}-3$ \\
\hline
\end{tabular}

\section{Discussion}

\subsection{Learnings from scenario analysis}

From the comparative LCA, the scenarios carrying lower environmental impacts are UBC scenarios, representing a can-to-can recycling, i.e. closed product loop option. This is valid for all impact categories and both LCIA methods considered. This result is aligned with the outcomes of a preliminary study conducted considering different types of aluminium scrap at $R R=57 \%$ (Niero et al. 2015a). However, when 
the uncertainty range is taken into account the robustness of this outcome can be confirmed only for the climate change impact category. The uncertainty range for the human health impact categories and resource depletion is too broad to draw any solid conclusion among the different scenarios. The contribution analysis at the process level for resource depletion shows the different substance coverage among the LCIA methods considered, which is one of the reasons leading to different impact scores and therefore different contribution to the normalized scores (Owsianiak et al. 2014). For the resource depletion impact category a lot of discussion is on-going to identify the best indicators and approaches to model the area of protection "resources" (see e.g. Mancini et al. 2014; Huysman et al. 2015). Our results are in accordance with Rørbech et al. (2014), in identifying the metal resources as the main contributor to the total impact score for the ILCD recommended method, and the energy resources for ReCiPe and CexD, respectively. However, among metals the most contributing to the overall impact is $\mathrm{Zn}$, which would be neglected if the traditional LCI modelling based on pure $\mathrm{Al}$ flow was considered.

Focusing on climate change impacts, a decreasing trend of the impacts with increasing \%RR can be identified. This confirms the environmental benefits of an improvement in the recycling rates of metals, to be performed either by increasing the collection rates of discarded products, or through enhanced deployment of modern recycling methodology (Gaustad et al. 2012; Reck and Graedel 2012). However, our results from the mass balance analysis highlight that at higher RR a higher \% Mn (corresponding to lower absolute mass of $\mathrm{Mn}$ ) needs to be added every cycle and a closed product loop is possible in the case of aluminium beverage can only with additional Mn supply. Not only can the accumulation of alloying elements be a limiting factor for the increase in collection rate, but also the accumulation of impurities and unintended chemicals, as shown by Løvik and Mueller (2014) for titanium dioxide from the lacquer used in aluminium beverage cans decoration and by Pivnenko et al. (2015) for chemicals used in the case of paper, respectively. Therefore, the accumulation of impurities and micro-contaminants through continuous recycling can threaten the aims of the circular economy, if no appropriate management of waste is put in place. One of the ways to retain the quality of recycled materials is to make the material flows as closed loops where possible, as shown in the case of plastic and paper waste (Lee et al. 2014) and here for the aluminium can. Paraskevas et al. (2015) concluded that container and packaging scrap can be fully utilised in the alloy used for the can body without any other primary material reaching the optimum $100 \%$ scrap utilization. We further showed that from an environmental point of view it makes sense to further separate between UBC and other MAP. The closed product loop option based on the same alloy has lower environmental impacts than the "product category" loop option. Therefore, differently from what is stated by the EAA (Labberton 2011), from an environmental point of view priorities should be established for the next use of UBC.

Different options have been already investigated to design an efficient closed-loop aluminium can supply chain, e.g. in the U.S. (Buffington and Peterson 2013): the development of a unialloy aluminium can or the 
establishment of a "voluntary deposit-refund system". An alternative to the unialloy can could be to separate the body and the lid at the point of collection, as pointed out by the sensitivity analysis, since no Mn would need to be added, even at the higher RR of $75 \%$ and $95 \%$. A further successful strategy emerging from the sensitivity analysis at the mass balance level points towards the development of cans with lighter lid weight, therefore increasing the amount of material to be recycled in a closed product loop. The viability of a deposit system for aluminium cans needs to be assessed also from an economic point of view and tailored to the local context (ERM 2008; Buffington 2014; Hogg et al. 2015). The possibility to establish a new business form in the UK market based on a closed UBC loop has been investigated by Stewart et al. (unpublished), focusing on both economic and environmental value creation, therefore exploiting the business aspects of the circular economy.

\subsection{Limitations and perspectives}

If we compare our results with the outcomes of the traditional LCA single Al flow modelling based of the traditional FU definition for the same case study of an aluminium can for the UK market with almost same assumptions (65\%RR, 50\% RC, 0\% RE) (Niero et al. 2016), we can notice that the score for the climate change impact category is almost double in the present study (MAP scenario, 65\% RR, 67.8\% RC, 0\%RE). This difference can be explained by the inclusion of the alloying elements production in can manufacturing, and recycling process, but most of all by the inclusion of the multiple recycling loops, as a consequence of the definition of "circular economy-inspired FU". This outcome proves the need of moving the LCA methodology from single to multiple life cycles modelling, already pointed out by Niero et al. (2016). Moreover, compared to the environmental assessment performed by Paraskevas et al. (2015), based on the ecoinvent v2.2 database, a significant difference can be found in the damage assessment for the Area of protection "resources" for 1 ton of primary aluminium production, i.e. from 47278 \$ (ecoinvent v2.2) to 349 \$ (ecoinvent v3.1, used in the present study). The damage assessment for 1 ton of $\mathrm{Mn}$ is equal to 12910 \$ (ecoinvent v3.1), therefore two orders of magnitude higher than the score for primary aluminium. This confirms that neglecting the presence of the alloying elements (in particular Mn) in the LCA modelling of aluminium products is a misleading assumption. The selection of the dataset used to represent material production and recycling is key, but also a source of variance, as pointed out by Brogaard et al. (2014).

With regard to recycling, it has been proven that collection schemes have an important influence on the LCA results (Laurent et al. 2014). In the present LCA study we did not include the transport during collection in the system boundaries. In the life cycle of an aluminium can, the impact from transport is indeed negligible. if compared to the metal production, at least for the climate change impact category (Stichling and NguyenNgoc 2009). However, we simulated the influence of the collection system on future scenarios and it turned out that a can-to-can recycling would provide a reduction of the impacts of $-26 \%$ for climate change and $22 \%$ for resource depletion compared to the MAP scenario (see Table 5). 
The discussion to what extent should closed product loop be promoted in the aluminium and metal sector is not straightforward. In the automotive sector priorities to enable increased aluminium and steel recycling include, e.g. increased dismantling of components before shredding, closed-loop recycling of safety-relevant cast parts (mainly wheels), as well as the development of technologies for automated sorting of shredded scrap (Nakajima et al. 2010; Hatayama et al. 2014; Løvik et al. 2014). Similar actions can be adopted also for aluminium beverage cans to enable the implementation of the circular economy. However, due to the overall limited availability of aluminium scrap, any attempt to increase the recycled content in one particular product would just result in decreasing the recycling content accordingly in another (EAA, 2006). The effects of implementing closed alloy recycling on the global aluminium market should be further investigated, as well as the correlation between the increase of $\% \mathrm{RR}$ and the $\% \mathrm{RC}$ in specific product categories, in view of the foreseen development of bauxite reserves and $\mathrm{Al}$ scrap availability, e.g. by the means of the system dynamics method, which is a powerful tool to support decision making throughout product multiple lifecycles (Asif et al. 2015; Sverdrup et al. 2015). To tackle the broader discussion on open loop recycling vs closed loop recycling the system boundary should include other types of uses for alloy 3004 (e.g. sheet-metal work, storage tanks, trailer panel sheet) and 5182 (e.g. automotive body panels and reinforcement members, brackets and parts) (The University of Liverpool 2015) or the impact of beverage cans escaping to close alloys or to different geographical markets, following the approach adopted by Paraskevas et al. (2015). However, the current study clarifies that there are trade-offs in the use of "aluminium packaging and container flow" and that the use of UBC scrap should be preferred over the use of mixed packaging aluminium scrap, due to the requirements in alloying elements thresholds.

According to Niero et al. (2016) one of the main challenges for LCA in the circular economy context is to address the continuous loop of materials and account for the benefits from recycling in a consistent way, with proper quantification of the substitution and downgrading factors. In this paper we proposed a way to model multiple life cycles through the definition of a "Circular economy-inspired FU", which considers as function of the can not only beer containment, but also the supply of resources after its use stage in multiple loops. How to consistently model the benefits of recycling requires tackling one of the bottlenecks of the traditional LCA modelling, i.e. that the quantification of quality degradation of metals during recycling is lacking (Amini et al. 2007). The idea of introducing a downgrading factor to take into account the quality of secondary material versus primary has been introduced in the most recent EoL formula developed in the context of the PEF methodology (Allacker et al. 2014). The quantification of the down-cycling issue in modelling aluminium recycling in LCA has already been tackled in terms of economic value of the scrap (Koffler and Florin 2013), but no guideline based on physical properties is available. Our suggestion is to use the outcome of our study to develop an alternative method to quantify the quality or downgrading factor, based on the alloying elements concentration and need for reintegration. 


\section{Conclusions}

The aim of this study was to investigate the effects of including the actual alloy composition in the LCA of aluminium can production and recycling, considering different scrap sources, in order to understand whether a can-to-can (i.e. closed product loop) recycling should be promoted or not. To provide an answer we performed a mass balance of the main alloying elements included in aluminium can body and lid considering 30 recycling loops, corresponding to a temporal interval of five years. We considered two sources for aluminium scrap representative of alternative scenarios: closed product category loop, where mixed aluminium packaging is used to manufacture new cans and closed product loop, where UBC are turned into new body cans. The limiting alloying element for continuous can-to-can recycling is $\mathrm{Mn}$, which needs to be reintegrated at higher \% with increasing \%RR (however corresponding to lower mass of $\mathrm{Mn}$ in absolute terms). We used the outcomes of the mass flow balance to quantify the amount of $\mathrm{Mn}$ and primary $\mathrm{Al}$ that needs to be reintegrated in each scenario according to the \%RR and used this information to perform an LCA based on the actual alloy composition. In terms of LCA methodology, we introduced the idea of multiple cofunctions in the functional unit definition and moved from one life cycle to multiple life cycle modelling. From the LCA the can-to-can option turned out to have lower environmental impact than the mixed aluminium packaging-to-can option, at least with regard to climate change. Therefore, in order to improve the environmental performances of the aluminium beverage can sector towards the implementation of a circular economy our main recommendations are: to reduce the weight of the lid, to develop methods to separate the body and lid at the point of collection, and to investigate the potentials of a closed supply chain loop for aluminium cans, e.g. through the establishment of "more efficient" collection systems, from an economic, environmental and consumer perspective. The model presented here for the UK market can be extended and applied to other markets, as well as further detailed e.g. with the inclusion of the transport during collection.

\section{Acknowledgments}

This work was supported by Carlsberg Foundation, Copenhagen, DK [grant number 2014_01_0005], who are deeply acknowledged for funding the project 'Design of Cradle to Cradle ${ }^{\circledR}$ - Inspired System for Beer Beverage Packaging". The authors would like to thank Simon Boas Hoffmeyer and Håkon Langen from Carlsberg Group for the inspiring discussion and support during data collection. We are also grateful to the three anonymous reviewers whose inputs and comments helped us in sharpening the content of the paper, as well as to Pradip Kalbar for his suggestions on how to improve the readability of figures. 


\section{References}

Allacker K, Mathieux F, Manfredi S, Pelletier N, De Camillis C, Ardente F, et al. Allocation solutions for secondary material production and end of life recovery: Proposals for product policy initiatives. Resour Conserv Recycl [Internet]. Elsevier B.V.; 2014;88:1-12. Available from: http://linkinghub.elsevier.com/retrieve/pii/S0921344914000834

Alupro. European recycling rate for beverage cans at a new record level [Internet]. 2015 [cited 2016 Jun 14]. Available from: http://www.alupro.org.uk/aluminium-recycling-news/european-recycling-rate-forbeverage-cans-at-a-new-record-level/

Amini SH, Remmerswaal J a. M, Castro MB, Reuter M a. Quantifying the quality loss and resource efficiency of recycling by means of exergy analysis. J Clean Prod [Internet]. 2007 Jan [cited 2014 Dec 8];15(10):907-13. Available from: http://linkinghub.elsevier.com/retrieve/pii/S095965260600062X

Asif FMA, Rashid A, Bianchi C, Nicolescu CM. System dynamics models for decision making in product multiple lifecycles. "Resources, Conserv Recycl [Internet]. Elsevier B.V.; 2015;101:20-33. Available from: http://dx.doi.org/10.1016/j.resconrec.2015.05.002

Berkhout B, Berting L, Bleeker Y, de Wit W, Kruis G, Stokkel R, et al. The Contribution made by Beer to the European Economy. Europe TB of, editor. Amsterdam (NL); 2013.

Bjørn A, Hauschild MZ. Absolute versus Relative Environmental Sustainability. J Ind Ecol [Internet]. 2013;17(2):321-32. Available from: http://doi.wiley.com/10.1111/j.1530-9290.2012.00520.x

Braungart M, McDonough W, Bollinger A. Cradle-to-cradle design: creating healthy emissions - a strategy for eco-effective product and system design. J Clean Prod [Internet]. 2007 Sep [cited 2014 Nov 10];15(13-14):1337-48. Available from: http://linkinghub.elsevier.com/retrieve/pii/S0959652606002587

Brogaard LK, Damgaard A, Jensen MB, Barlaz M, Christensen TH. Evaluation of life cycle inventory data for recycling systems. Resour Conserv Recycl [Internet]. Elsevier B.V.; 2014 Jun [cited 2014 Dec 9];87:30-45. Available from: http://linkinghub.elsevier.com/retrieve/pii/S092134491400069X

Buffington J. The viability of a "voluntary refund-deposit system" for aluminum can recycling in the U.S. Light Met. 2014;913-8.

Buffington J, Peterson R. Defining a closed-loop U.S. aluminum can supply chain through technical design and supply chain innovation. Jom. 2013;65(8):941-50.

Bösch ME, Hellweg S, Huijbregts M a. J, Frischknecht R. Applying cumulative exergy demand (CExD) indicators to the ecoinvent database. Int J Life Cycle Assess. 2007;12(3):181-90.

Castro MBG, Remmerswaal J a M, Reuter M a., Boin UJM. A thermodynamic approach to the compatibility of materials combinations for recycling. Resour Conserv Recycl. 2004;43(1):1-19.

CIRAIG. Circular economy: a critical literature review of concepts. Montréal (Québec) Canada; 2015.

Ciroth A, Muller S, Weidema B, Lesage P. Empirically based uncertainty factors for the pedigree matrix in ecoinvent. Int J Life Cycle Assess [Internet]. 2013 Dec 20 [cited 2014 Feb 27]; Available from: http://link.springer.com/10.1007/s11367-013-0670-5

Cordella M, Tugnoli A, Spadoni G, Santarelli F, Zangrando T. LCA Case Studies LCA of an Italian Lager Beer. Int J Life Cycle Assess. 2008;13(2):133-9.

Detzel A, Mönckert J. Environmental evaluation of aluminium cans for beverages in the German context. Int J Life Cycle Assess [Internet]. 2009 Feb 21 [cited 2014 Nov 17];14(S1):70-9. Available from: http://link.springer.com/10.1007/s11367-008-0057-1

EC. Commission Recommendation of 9 April 2013 on the use of common methods to measure and 
communicate the life cycle environmental performance of products and organisations. European Commission, Brussels; 2013.

EC. Communication from the Commission to teh European Parliament, the Council, the European Economic and Social Comitee and the Commitee of the regions. Closing the loop - An EU action plan for the Circular Economy. European Commission, Brussels; 2015a.

EC. Proposal for a DIRECTIVE OF THE EUROPEAN PARLIAMENT AND OF THE COUNCIL amending Directive 94/62/EC on packaging and packaging waste. COM(2015)0276 (COD). 2015 b.

EC-JRC-IES. International Reference Life Cycle Data System (ILCD) Handbook- Recommendations for Life Cycle Impact Assessment in the European context. First edit. Luxemburg: EUR 24571 EN. Publications Office of the European Union; 2011.

EMF. Towards the circular economy. Opportunities for the consumer goods sector. Ellen MacArthur Foundation; 2013.

ERM. Review of Packaging Deposits System for the UK. Final Report. 2008.

EAA. Aluminium recycling in Europe: the road to high quality products [Internet]. Eur. Alum. Assoc. Brussels. 2006. Available from: http://scholar.google.com/scholar?hl=en\&btnG=Search\&q=intitle:Aluminium+recycling+the+road+to+ high+quality+products\#0

EAA. Aluminium Used Beverage Can Recycling Results, Europe 2009. 2010.

EAA. Environmental Profile Report for the European Aluminium Industry April 2013- Data for the year 2010 Life Cycle Inventory data for aluminium production and transformation processes in Europe. European Alluminium Association; 2013.

EAA. Press Release. Recycling rate for cans at new record level [Internet]. 2015 [cited 2016 Jun 14]. p. 1-2. Available from: http://european-aluminium.eu/media/1285/201503_recycling-rate-for-cans-at-newrecord-level_europeanaluminium.pdf

Frischknecht R, Jungbluth N, Althaus H-J, Doka G, Heck T, Hellweg S, et al. Overview and Methodology. Ecoinvent Report No. 1. Swiss Centre for Life Cycle Inventories. Dübendorf, Switzerland; 2007.

Gaustad G, Li P, Kirchain R. Modeling methods for managing raw material compositional uncertainty in alloy production. Resour Conserv Recycl [Internet]. 2007 Dec [cited 2014 Dec 10];52(2):180-207. Available from: http://linkinghub.elsevier.com/retrieve/pii/S0921344907000535

Gaustad G, Olivetti E, Kirchain R. Improving aluminum recycling: A survey of sorting and impurity removal technologies. Resour Conserv Recycl [Internet]. Elsevier B.V.; 2012 Jan [cited 2014 Dec 4];58:79-87. Available from: http://linkinghub.elsevier.com/retrieve/pii/S0921344911002217

Goedkoop M, Heijungs R, Huijbregts M, De Schryver A, Struijs J, R van Z. ReCiPe 2008, A life cycle impact assessment method which comprises harmonised category indicators at the midpoint and the endpoint level [Internet]. 2009. Available from: http://www.lcia-recipe.net

Hatayama H, Daigo I, Matsuno Y, Adachi Y. Evolution of aluminum recycling initiated by the introduction of next-generation vehicles and scrap sorting technology. Resour Conserv Recycl [Internet]. Elsevier B.V.; 2012 Sep [cited 2014 Dec 5];66:8-14. Available from: http://linkinghub.elsevier.com/retrieve/pii/S0921344912001036

Hatayama H, Daigo I, Tahara K. Tracking effective measures for closed-loop recycling of automobile steel in China. Resour Conserv Recycl [Internet]. Elsevier B.V.; 2014 Jun [cited 2014 Dec 5];87:65-71. Available from: http://linkinghub.elsevier.com/retrieve/pii/S0921344914000640

Hauschild MZ, Goedkoop M, Guinée J, Heijungs R, Huijbregts M, Jolliet O, et al. Identifying best existing practice for characterization modeling in life cycle impact assessment. Int $\mathrm{J}$ Life Cycle Assess 
[Internet]. 2013 Sep 12;18(3):683-97. Available from: http://link.springer.com/10.1007/s11367-012$0489-5$

Hauschild MZ, Huijbregts M, Jolliet O, Macleod M, Margni M, Meent V De, et al. Building a model based on scienti c consensus for life cycle impact assessment of chemicals: the search for harmony and parsimony. Environ Sci Technol. 2008;42(19):7032-7.

Hogg D, Elliott T, Gibbs A, Jones P, Eye M Von, Hann S, et al. A Scottish Deposit Refund system. Final Report for Zero Waste Scotland. Bristol (UK); 2015.

Huysman S, Sala S, Mancini L, Ardente F, Alvarenga R a. F, De Meester S, et al. Toward a systematized framework for resource efficiency indicators. Resour Conserv Recycl [Internet]. Elsevier B.V.; 2015;95:68-76. Available from: http://dx.doi.org/10.1016/j.resconrec.2014.10.014

IEA. Energy technology transitions for industry the Next Industrial [Internet]. Int. Energy Agency. 2009. Available from: www.iea.org

IEC. Environmental Product Declaration (EPD) certified. Carlsberg Beer. 2014.

ISO. Environmental management. Life cycle assessment. Principle and framework. ISO 14040:2006. Geneva, Switzerland; 2006a.

ISO. Environmental management. Life cycle assessment. Requirements and guidelines. ISO 14044:2006. Geneva, Switzerland; 2006b.

Klinglmair M, Sala S, Brandão M. Assessing resource depletion in LCA: a review of methods and methodological issues. Int J Life Cycle Assess [Internet]. 2013 Sep 10 [cited 2015 Jan 21];19(3):58092. Available from: http://link.springer.com/10.1007/s11367-013-0650-9

Koffler C, Florin J. Tackling the Downcycling Issue-A Revised Approach to Value-Corrected Substitution in Life Cycle Assessment of Aluminum (VCS 2.0). Sustainability [Internet]. 2013 Oct 25 [cited 2014 Dec 3];5(11):4546-60. Available from: http://www.mdpi.com/2071-1050/5/11/4546/

Koroneos C, Roumbas G, Gabari Z, Papagiannidou E, Moussiopoulos N. Life cycle assessment of beer production in Greece. J Clean Prod [Internet]. 2005 Mar [cited 2014 Dec 8];13(4):433-9. Available from: http://linkinghub.elsevier.com/retrieve/pii/S0959652603001628

Labberton MG. Progress on Aluminium Packaging Recycling in Europe - focus on beverage cans : deposit systems versus other collection schemes. 2011.

Laurent A, Clavreul J, Bernstad A, Bakas I, Niero M, Gentil E, et al. Review of LCA studies of solid waste management systems--part II: methodological guidance for a better practice. Waste Manag [Internet]. Elsevier Ltd; 2014 Mar;34(3):589-606. Available from: http://www.ncbi.nlm.nih.gov/pubmed/24388596

Laurent A, Olsen SI, Hauschild MZ. Carbon footprint as environmental performance indicator for the manufacturing industry. CIRP Ann - Manuf Technol [Internet]. CIRP; 2010 Jan [cited 2015 Jan 11];59(1):37-40. Available from: http://linkinghub.elsevier.com/retrieve/pii/S0007850610000090

Lee J, Pedersen AB, Thomsen M. The influence of resource strategies on childhood phthalate exposureThe role of REACH in a zero waste society. Environ Int [Internet]. Elsevier Ltd; 2014;73:312-22. Available from: http://linkinghub.elsevier.com/retrieve/pii/S0160412014002517

Leroy C. Provision of LCI data in the European aluminium industry Methods and examples [Internet]. Int. J. Life Cycle Assess. 2009 [cited 2015 Mar 23]. Available from: http://link.springer.com/10.1007/s11367009-0068-6

Li N, Qiu K. Study on delacquer used beverage cans by vacuum pyrolysis for recycle. Environ Sci Technol [Internet]. 2013 Oct 15;47(20):11734-8. Available from: http://www.ncbi.nlm.nih.gov/pubmed/24070094 
Liu G, Bangs CE, Müller DB. Stock dynamics and emission pathways of the global aluminium cycle. Nat Clim Chang [Internet]. Nature Publishing Group; 2012 Oct 7 [cited 2014 Dec 1];3(4):338-42. Available from: http://www.nature.com/doifinder/10.1038/nclimate1698

Liu G, Müller DB. Addressing sustainability in the aluminum industry: a critical review of life cycle assessments. J Clean Prod [Internet]. 2012 Nov [cited 2014 Dec 3];35:108-17. Available from: http://linkinghub.elsevier.com/retrieve/pii/S0959652612002533

Løvik A., Mueller DB. A Material Flow Model for Impurity Accumulation in Beverage Can Recycling Systems. Light Met. 2014;907-11.

Løvik AN, Modaresi R, Muller DB. Long-Term Strategies for Increased Recycling of Automotive Aluminum and Its Alloying Elements. Environ Sci Technol. 2014;48:4257-65.

Mancini L, Sala S, Recchioni M, Benini L, Goralczyk M, Pennington D. Potential of life cycle assessment for supporting the management of critical raw materials. Int J Life Cycle Assess. 2014;100-16.

McDonough W, Braungart M. Cradle to cradle. North Point Press. New York; 2002.

Moreno Ruiz E, Lévová T, Bourgault G, Wernet G. Documentation of changes implemented in ecoinvent Data 3.1. Ecoinvent. Zurich; 2014.

Muchová L, Eder P. End-of-waste Criteria for Aluminium and Aluminium Alloy Scrap : Technical Proposals. Union E, editor. 2010.

Nakajima K, Takeda O, Miki T, Matsubae K, Nakamura S, Nagasaka T. Thermodynamic analysis of contamination by alloying elements in aluminum recycling. Environ Sci Technol [Internet]. $2010 \mathrm{Jul}$ 15;44(14):5594-600. Available from: http://www.ncbi.nlm.nih.gov/pubmed/20536230

Nakamura S, Kondo Y, Matsubae K, Nakajima K, Tasaki T, Nagasaka T. Quality- and dilution losses in the recycling of ferrous materials from end-of-life passenger cars: Input-output analysis under explicit consideration of scrap quality. Environ Sci Technol. 2012;46(17):9266-73.

Nessi S, Rigamonti L, Grosso M. Discussion on methods to include prevention activities in waste management LCA. Int J Life Cycle Assess [Internet]. 2013 May 22 [cited 2014 Dec 10];18(7):135873. Available from: http://link.springer.com/10.1007/s11367-013-0570-8

Niero M, Hoffmeyer SB, Langen H, Olsen SI. The Hamlet dilemma of aluminium cans in the circular economy: to be or not to be in a closed loop? In: Scalbi S, Dominici Lorpieno A, Sposato P, editors. Int Conf Life Cycle Assess as Ref Methodol Assess supply Chain Support Glob Sustain challenges. Roma: ENEA; 2015a. p. 351-4.

Niero M, Ingvordsen CH, Jørgensen RB, Hauschild MZ. How to manage uncertainty in future Life Cycle Assessment (LCA) scenarios addressing the effect of climate change in crop production. J Clean Prod [Internet]. Elsevier Ltd; 2015b;107:693-706. Available from: http://linkinghub.elsevier.com/retrieve/pii/S0959652615006162

Niero M, Negrelli AJ, Boas SH, Olsen SI, Birkved M. Closing the loop for aluminium cans: Life Cycle Assessment of progression in Cradle-to-Cradle certification levels. J Clean Prod 101016/j.jclepro201602122. 2016;

Owsianiak M, Laurent A, Bjørn A, Hauschild MZ. IMPACT 2002+, ReCiPe 2008 and ILCD's recommended practice for characterization modelling in life cycle impact assessment: a case studybased comparison. Int J Life Cycle Assess [Internet]. 2014 Mar 8 [cited 2014 Mar 10]; Available from: http://link.springer.com/10.1007/s11367-014-0708-3

Paraskevas D, Kellens K, Dewulf W, Duflou JR. Environmental modelling of aluminium recycling: a Life Cycle Assessment tool for sustainable metal management. J Clean Prod [Internet]. 2015;105:357-70. Available from: http://linkinghub.elsevier.com/retrieve/pii/S0959652614010646 
PE Americas. Life Cycle Impact Assessment of Aluminum Beverage Cans. Final Report. 2010.

Pivnenko K, Eriksson E, Astrup TF. Waste paper for recycling: Overview and identification of potentially critical substances. Waste Manag [Internet]. Elsevier Ltd; 2015; Available from: http://linkinghub.elsevier.com/retrieve/pii/S0956053X15001312

PRé. Introduction to LCA with SimaPro. PRé; 2013.

Reck BK, Graedel TE. Challenges in metal recycling. Science [Internet]. 2012 Aug 10 [cited 2014 Dec 1];337(6095):690-5. Available from: http://www.ncbi.nlm.nih.gov/pubmed/22879508

van Renssen S. Making more with less. Nat Clim Chang [Internet]. Nature Publishing Group; 2011 Jun [cited 2014 Dec 8];1(3):137-8. Available from: http://www.nature.com/doifinder/10.1038/nclimate1133

Rigamonti L, Grosso M, Giugliano M. Life cycle assessment of sub-units composing a MSW management system. J Clean Prod [Internet]. Elsevier Ltd; 2010 Nov [cited 2014 Dec 10];18(16-17):1652-62. Available from: http://linkinghub.elsevier.com/retrieve/pii/S0959652610002568

Rombach G. Raw material supply by aluminium recycling - Efficiency evaluation and long-term availability. Acta Mater [Internet]. Acta Materialia Inc.; 2013 Feb [cited 2014 Dec 8];61(3):1012-20. Available from: http://linkinghub.elsevier.com/retrieve/pii/S1359645412006386

Rørbech JT, Vadenbo C, Hellweg S, Astrup TF. Impact Assessment of Abiotic Resources in LCA: Quantitative Comparison of Selected Characterization Models. Environ Sci Technol [Internet]. 2014;48(19):11072-81. Available from: http://www.ncbi.nlm.nih.gov/pubmed/25208267

Sevigné-Itoiz E, Gasol CM, Rieradevall J, Gabarrell X. Environmental consequences of recycling aluminum old scrap in a global market. Resour Conserv Recycl [Internet]. Elsevier B.V.; 2014 Aug [cited 2014 Dec 3];89:94-103. Available from: http://linkinghub.elsevier.com/retrieve/pii/S0921344914001086

Stewart R, Niero M, Murdock K, Olsen SI. Exploring the business challenges of a closed-loop supply: the case of aluminum beverage cans. unpublished.

Stichling J, Nguyen-Ngoc D. Life Cycle Inventory and Impact Analysis for Beverage Cans. Final Report. PE International; 2009.

Sverdrup HU, Ragnarsdottir KV, Koca D. Aluminium for the future: Modelling the global production, market supply, demand, price and long term development of the global reserves. Resour Conserv Recycl [Internet]. Elsevier B.V.; 2015;103:139-54. Available from: http://dx.doi.org/10.1016/j.resconrec.2015.06.008

Talve S. LCA Case Studies Life Cycle Assessment of a Basic Lager Beer. Int J Life Cycle Assess. 2001;6(5):293-8.

The University of Liverpool. Aluselect [Internet]. 2015 [cited 2015 Sep 15]. Available from: http://aluminium.matter.org.uk/aluselect/06_wrought_comp.asp

UNEP \& SETAC. Analysis of Life Cycle Assessment in Packaging for Food \& Beverage Applications. United Nations Environmental Programme Society of Environmental Toxicology and Chemistry Life Cycle Initiative; 2013.

Wang M, Woo K Do, Kim DK, Ma L. Study on de-coating used beverage cans with thick sulfuric acid for recycle. Energy Convers Manag. 2007;48(3):819-25. 


\section{List of Figure captions}

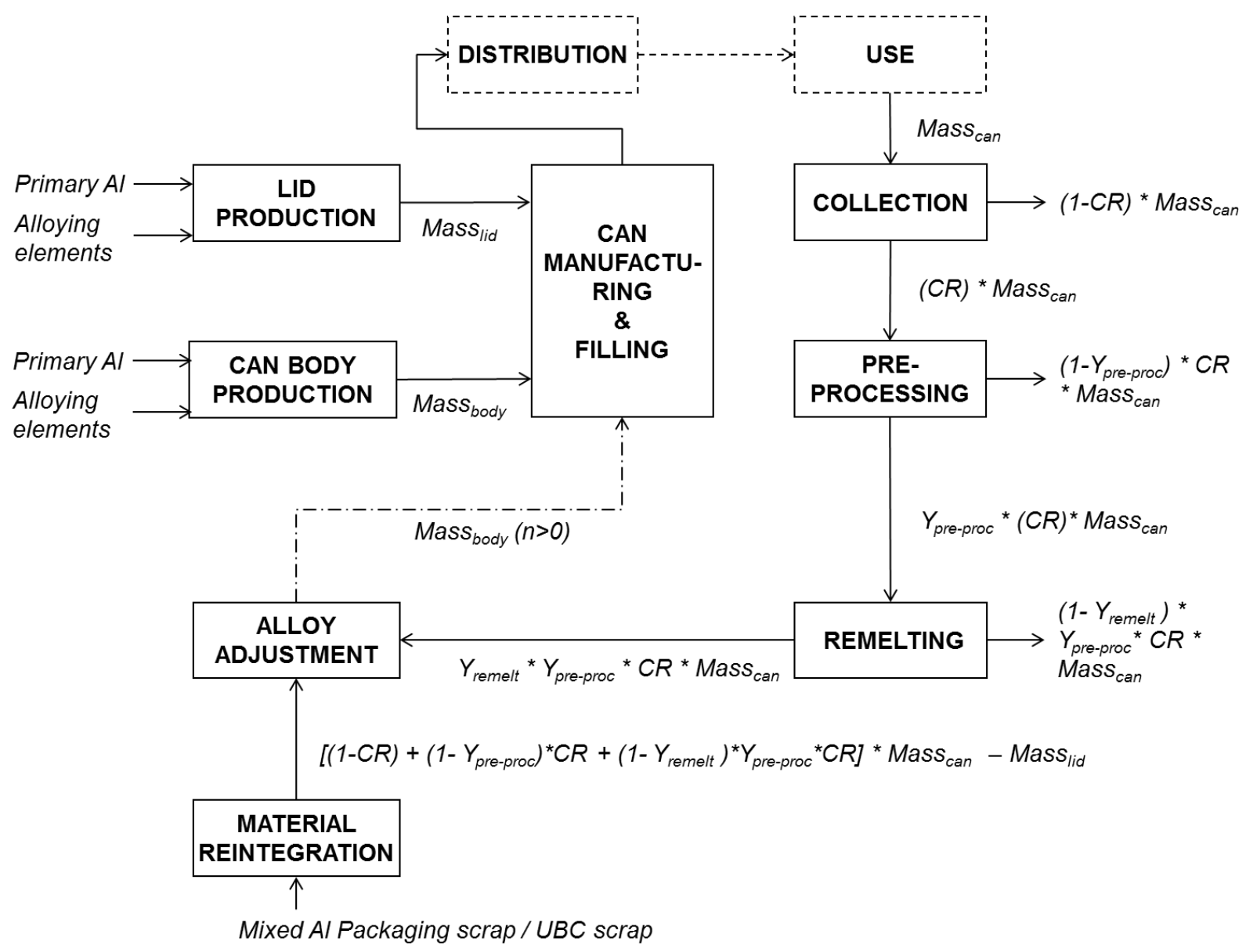

Fig. 1. System boundaries definition for mass balance of alloying elements and $\mathrm{Al}$ in aluminium beverage can manufacturing (i.e. lid and can body production, filling) and recycling (including collection, preprocessing, remelting and alloy adjustment). The dashed arrow refers to the mass body input after one recycling loop $(n>0)$, meanwhile dashed boxes indicate exclusions from the system. $\mathrm{CR}=$ Collection Rate; $\mathrm{Y}_{\text {pre-proc }}=$ yield during pre-processing step, $\mathrm{Y}_{\text {remelt }}=$ yield during remelting. For material reintegration two alternative scrap sources are used: Used Beverage Can scrap and Mixed Aluminium Packaging scrap. 
a)
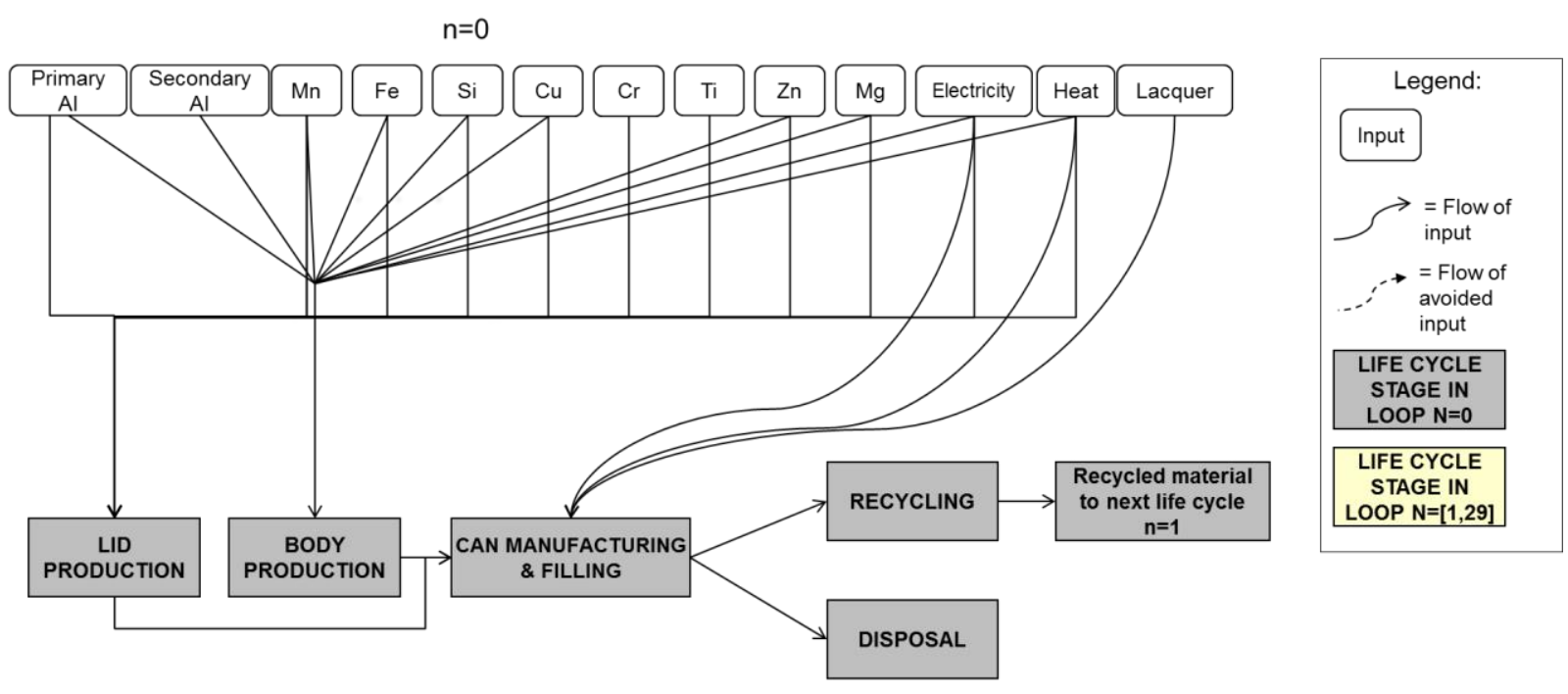

b) $\mathrm{n}=[1,29]$

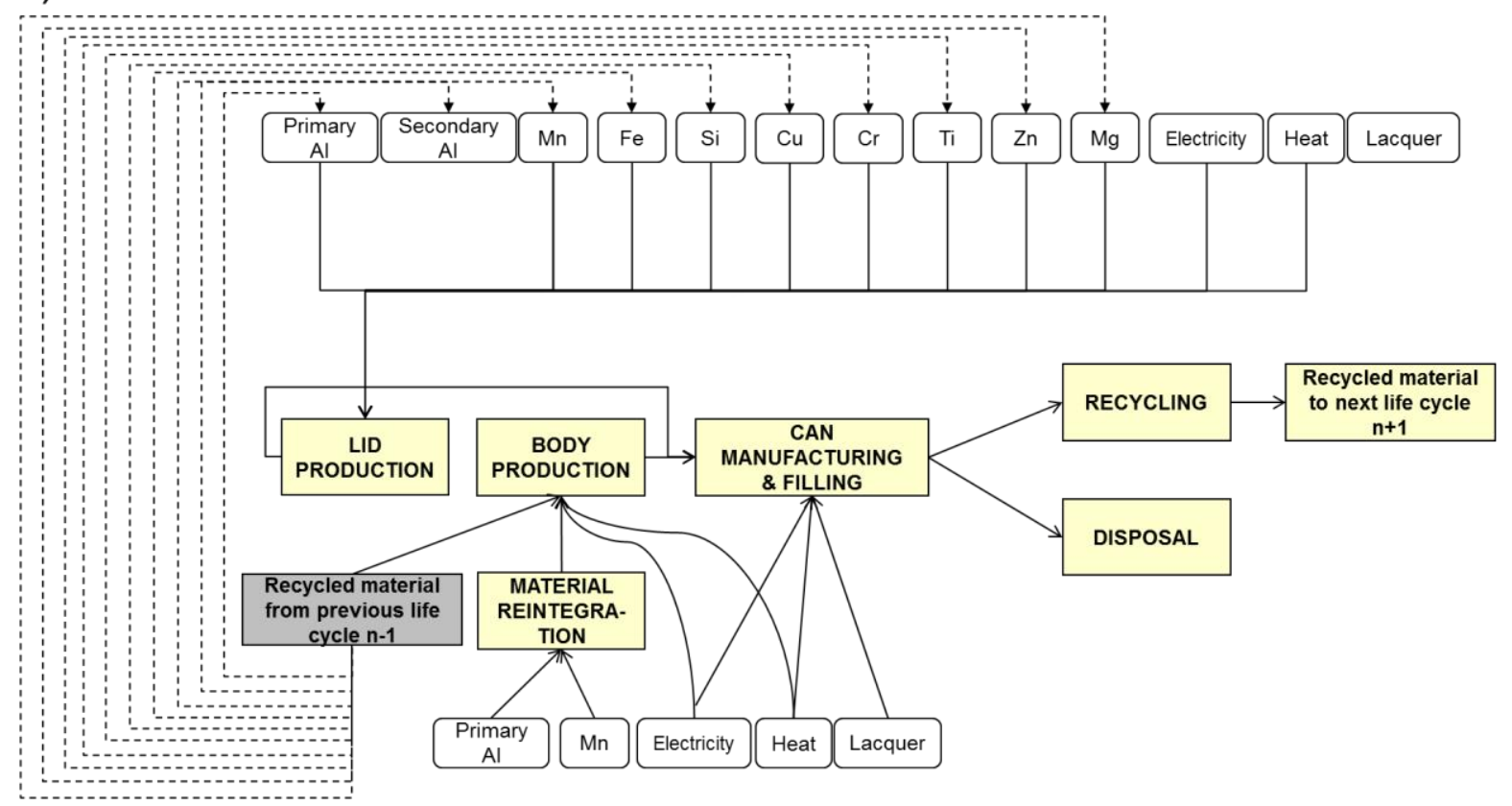

Fig. 2. Schematic representation of the product system considered in the "multi loops LCA", namely a) loop $n=0$ and $b$ ) loops $n=[1: 29]$, where the main input to each life cycle stages, i.e. lid production, body production, can manufacturing and filling, end-of-life including disposal and recycling, material reintegration, are represented. 
Niero \& Olsen (2016) Resources Conservation and Recycling 114, 18-31 http://dx.doi.org/10.1016/j.resconrec.2016.06.023
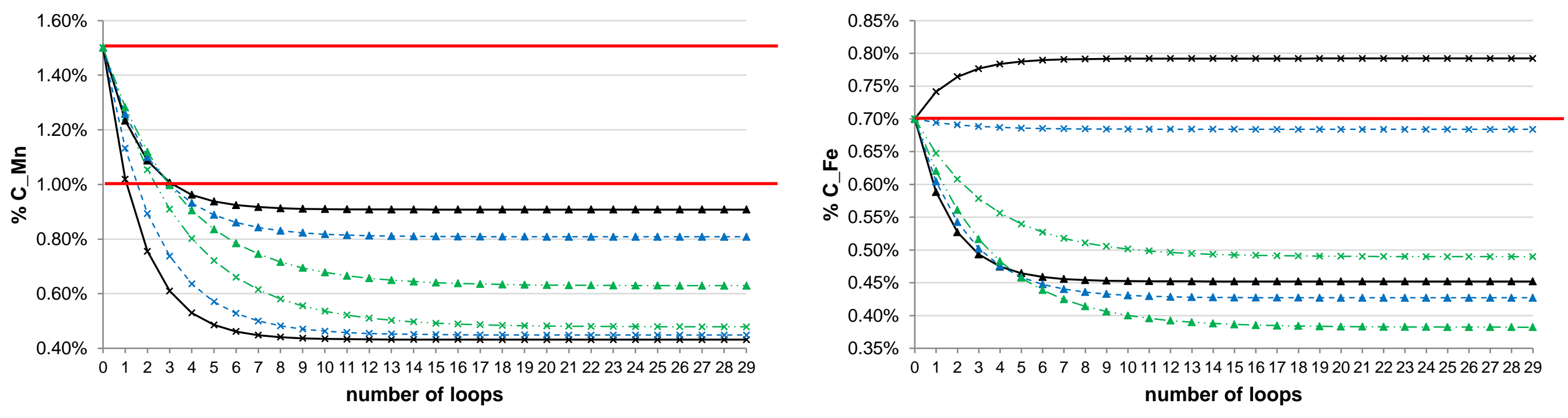


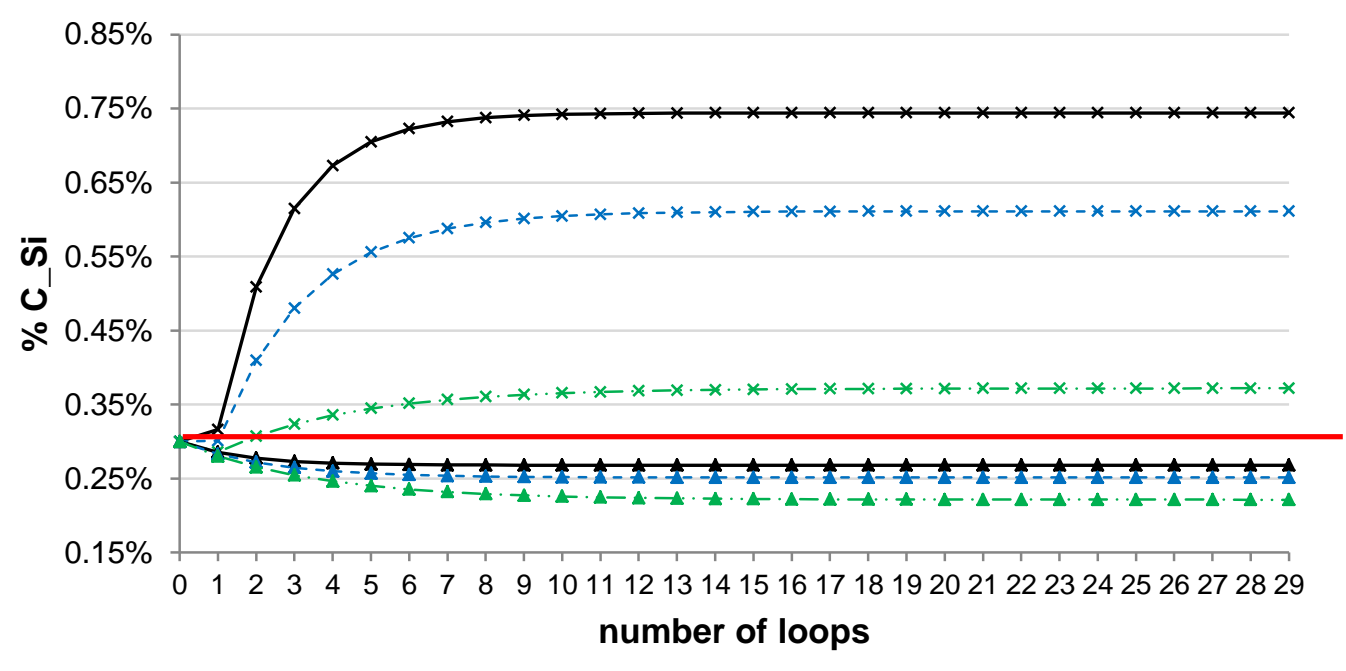

http://dx.doi.org/10.1016/j.resconrec.2016.06.023

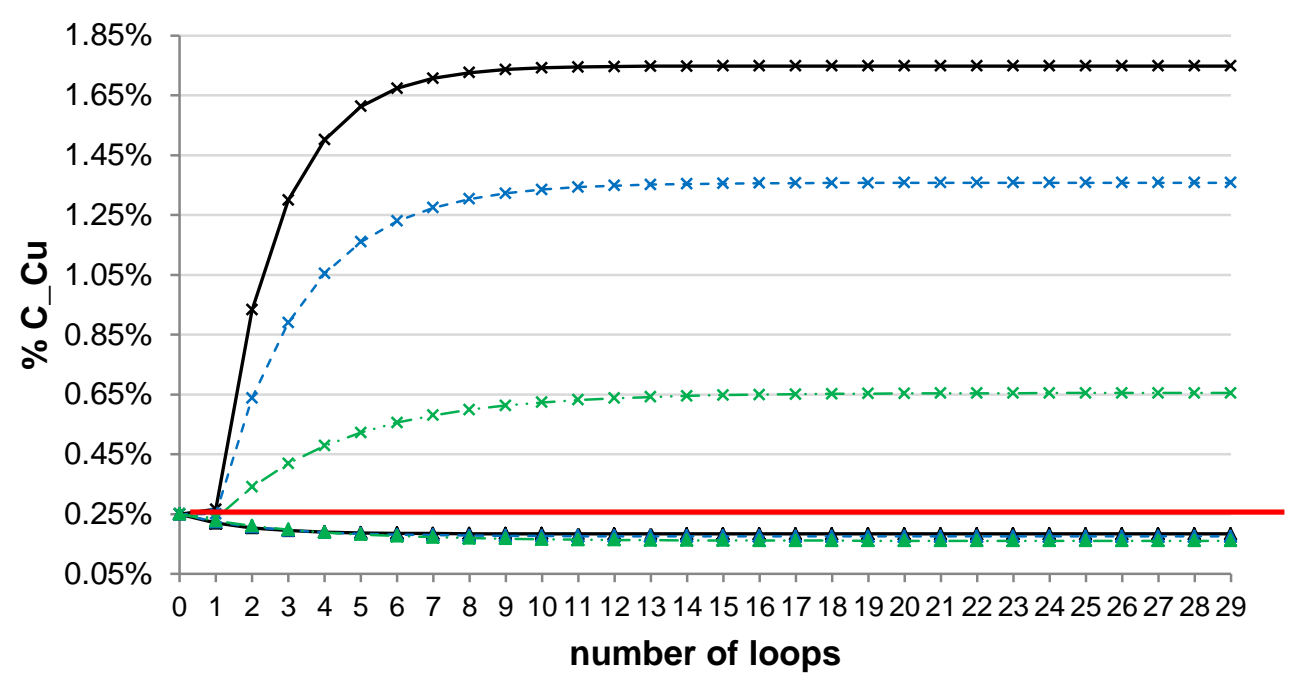

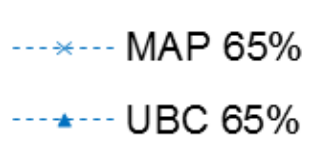

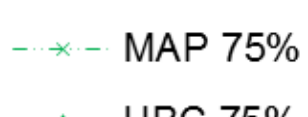

$-\cdots-$ UBC $75 \%$

Fig. 3. Mass fraction of alloying elements (\%) over the 30 modelled loops $n=[0,29]$, according to the two sets of scrap source (MAP=Mixed Aluminium Packaging scrap; UBC=Used Beverage Can scrap) for the three sets of $\%$ RR, i.e. 55\%, 65\%, 75\%. The red straight lines represent the thresholds for alloying elements mass fraction (\%C_i) in the body, i.e. a) Mn: $1.0-1.5 \%$; b) Fe: $<0.7 \%$; c) $\mathrm{Si}:<0.3 \%$; d) $\mathrm{Cu}:<0.25 \%$. 


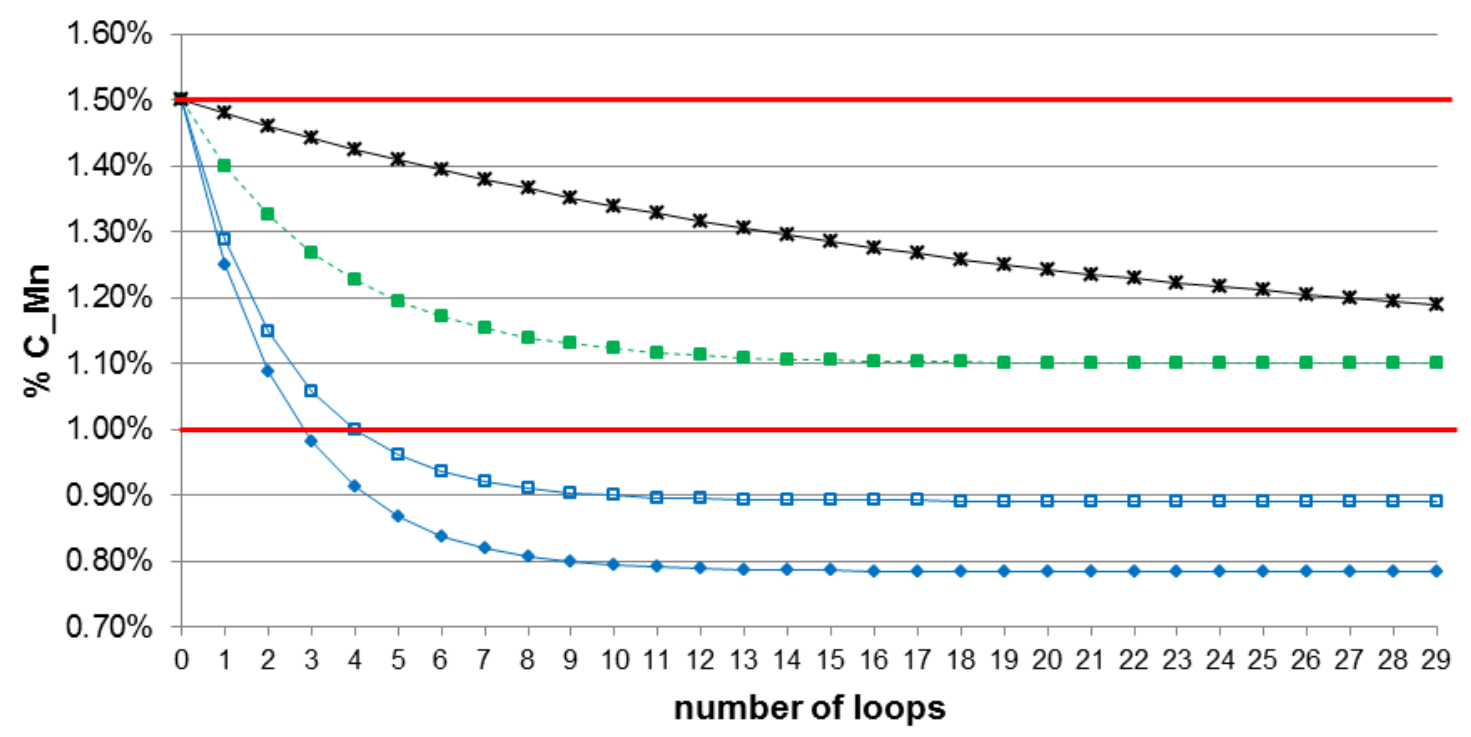

$\square$ RR=65\% Decreased lid weight —- RR=65\% Decreased body weight

...- RR=75\% Body and lid separation — - RR=95\% Body and lid separation

Fig. 4. Mn mass fraction (\%C_Mn) over the 30 modelled loops $n=[0,29]$, for the UBC=Used Beverage Can scenario at $\mathrm{RR}=65 \%$, when the body weight is increased or decreased, and in case of separation of body and lid (at RR=75\% and 95\%). The red straight lines represent the thresholds for Mn concentration in the body, i.e. $1.0-1.5 \%$. 
a

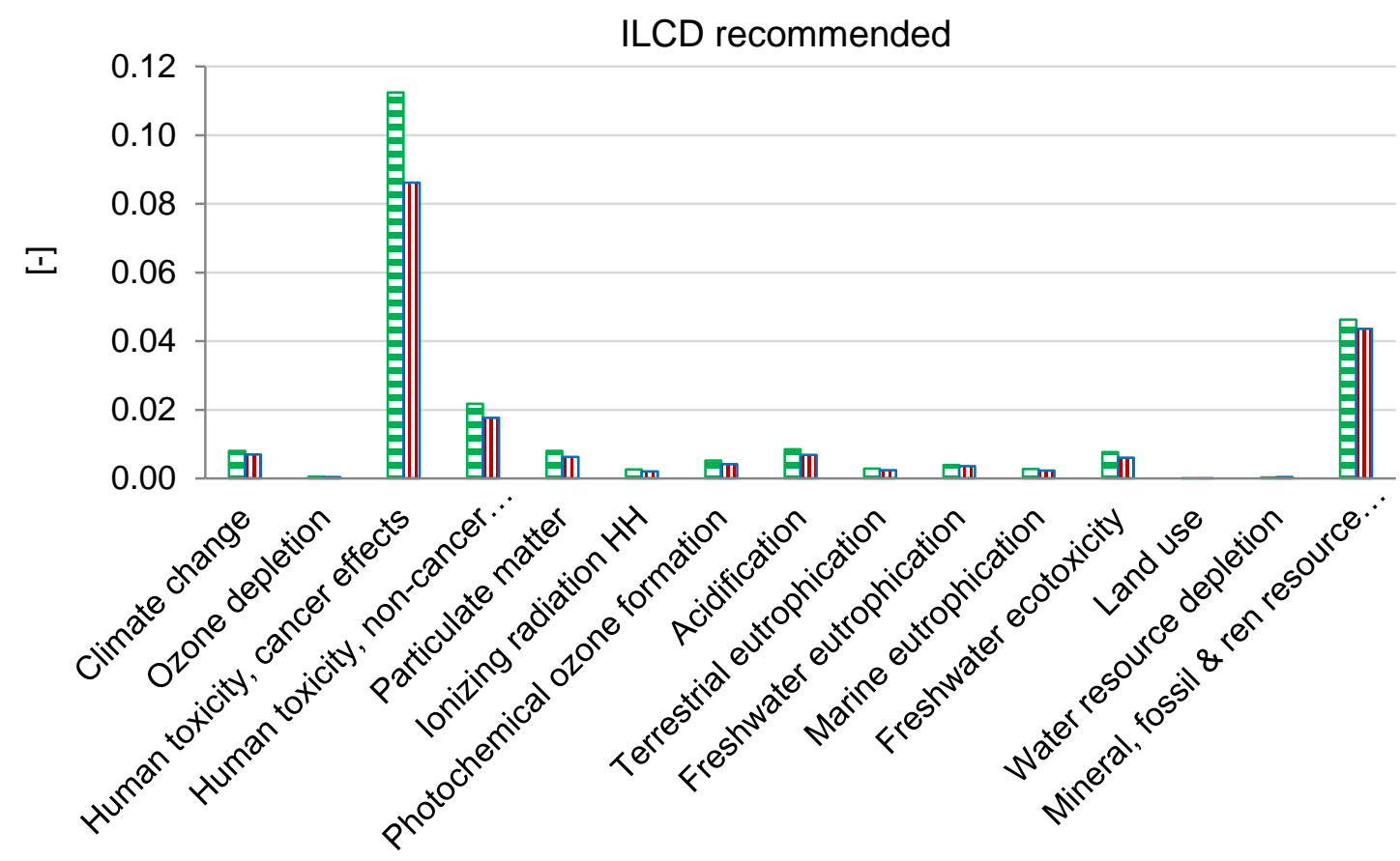

b

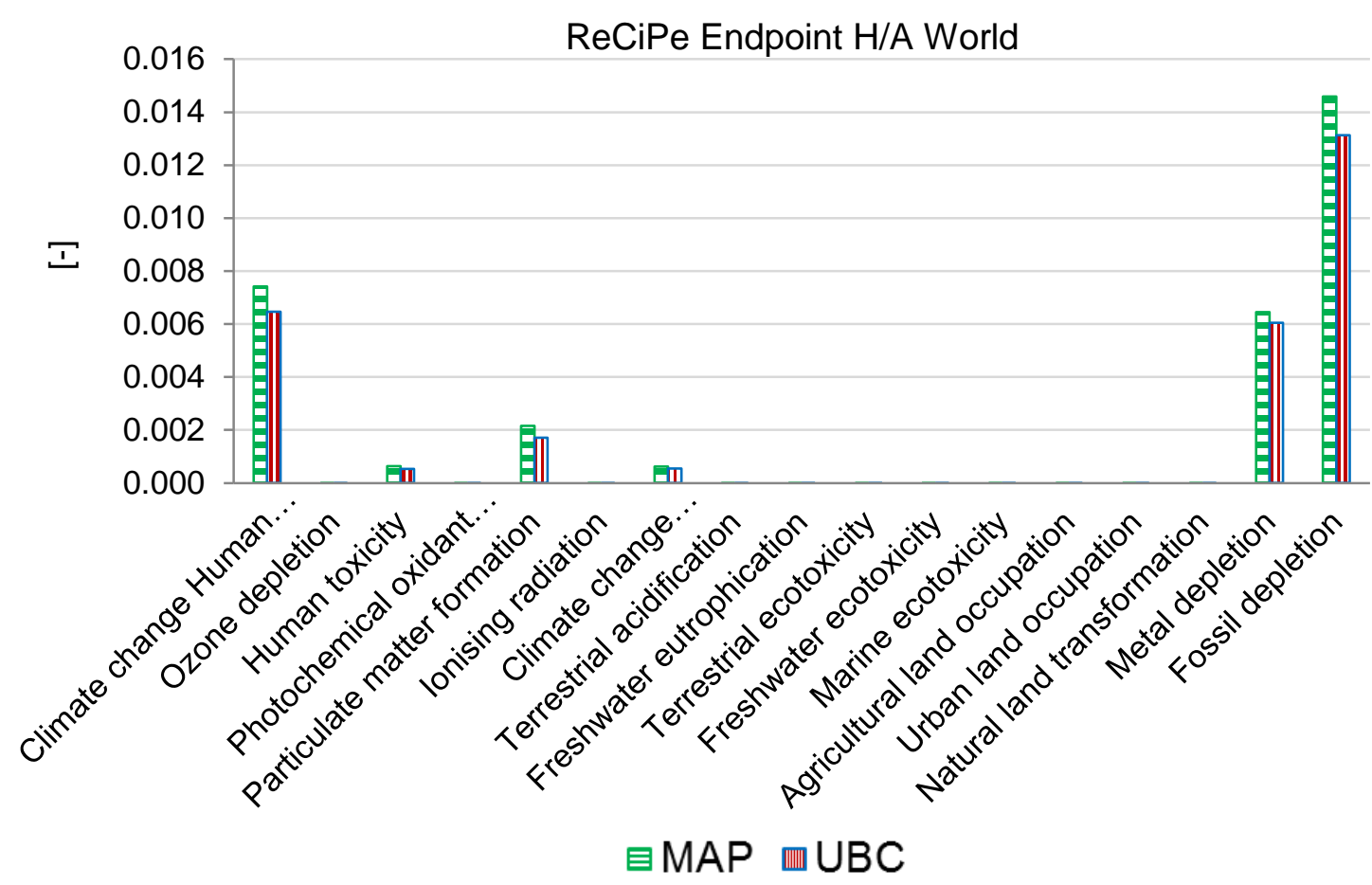

Fig. 5. Life Cycle Impact Assessment results after normalization for 30 loops according to the two alternative scenarios (MAP=Mixed Aluminium Packaging, UBC=Used Beverage Can) at RR=65\% based on a) ILCD 2011 midpoint and b) ReCiPe endpoint H/A world. 


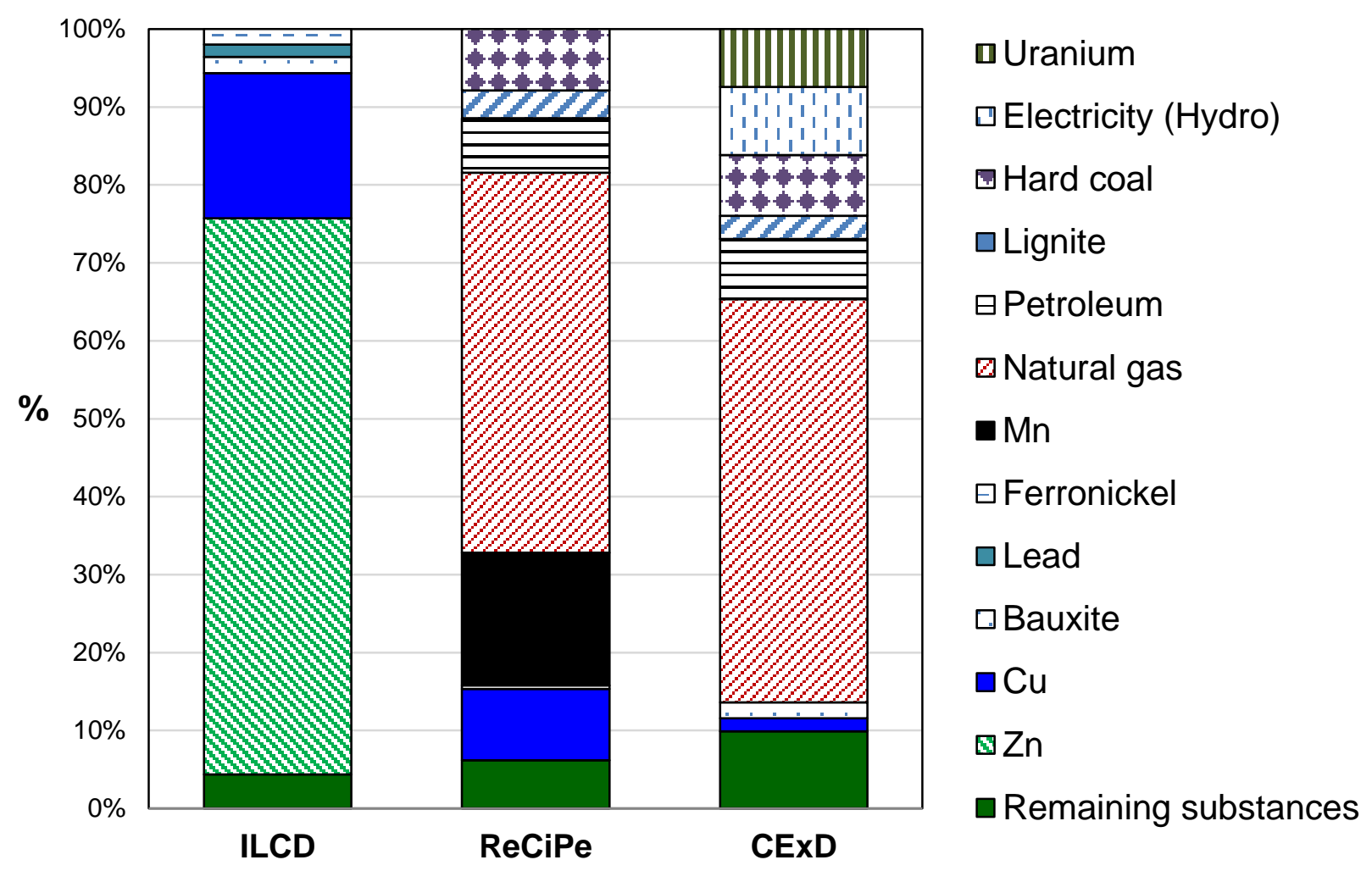

Fig. 6. Contribution analysis at the process level for the UBC scenario with $\mathrm{RR}=65 \%$ for resource depletion impact category, according to ILCD recommended, ReCiPe endpoint and CExD. 


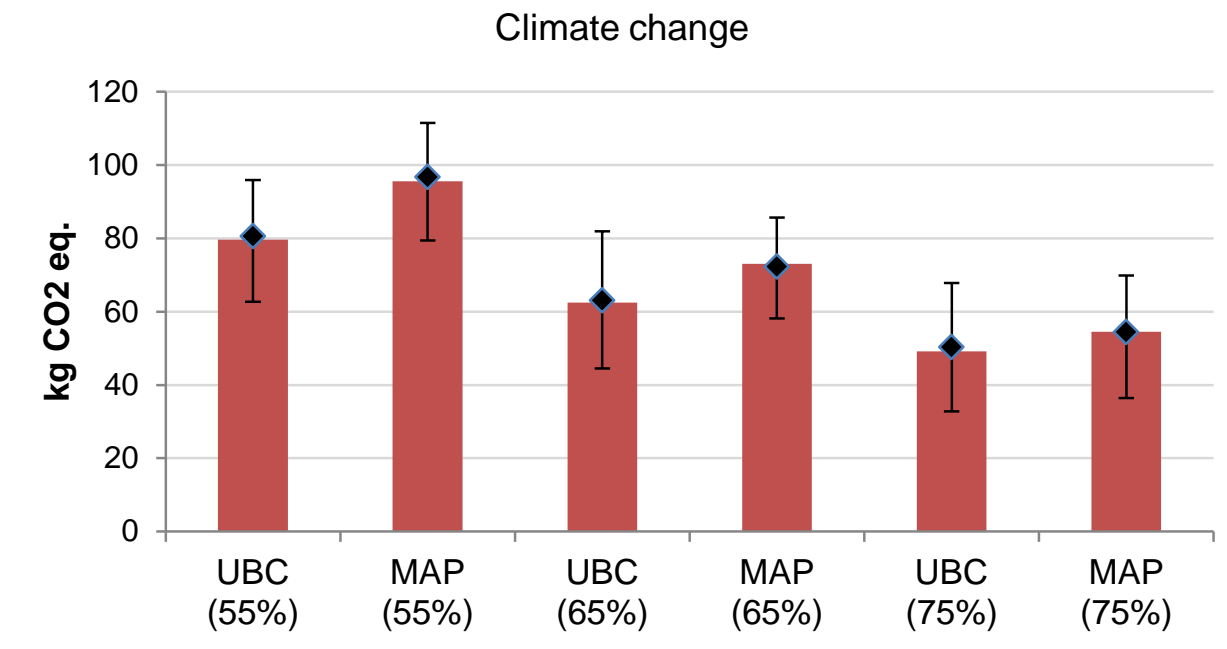

C

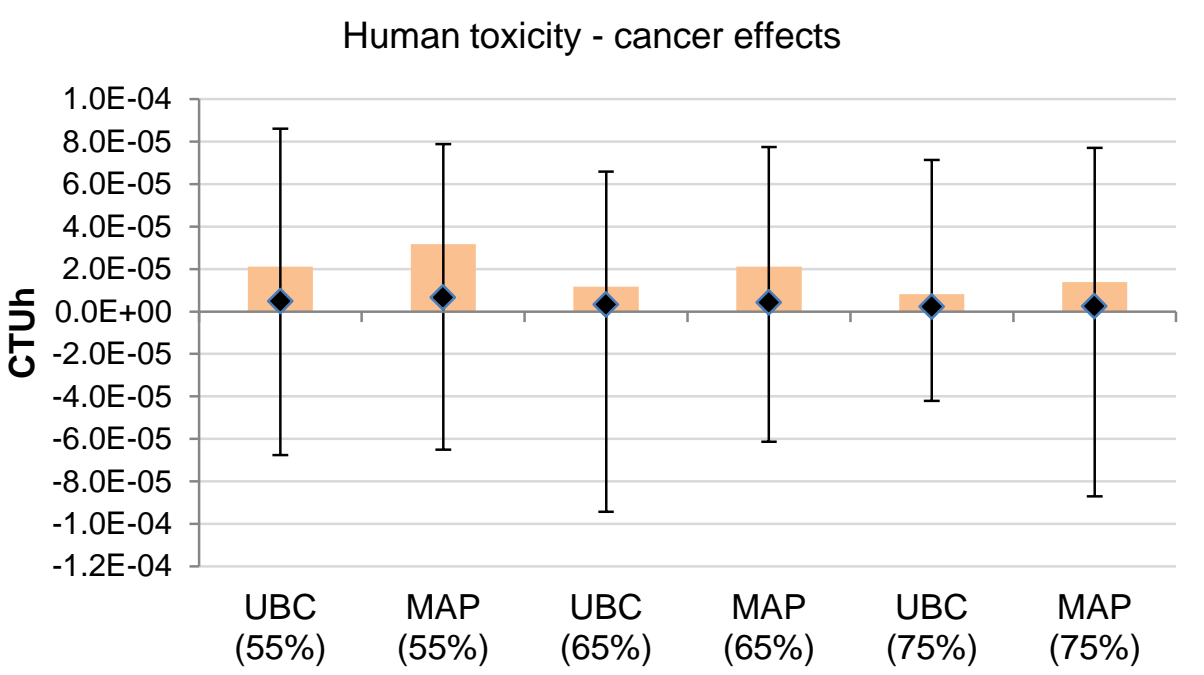

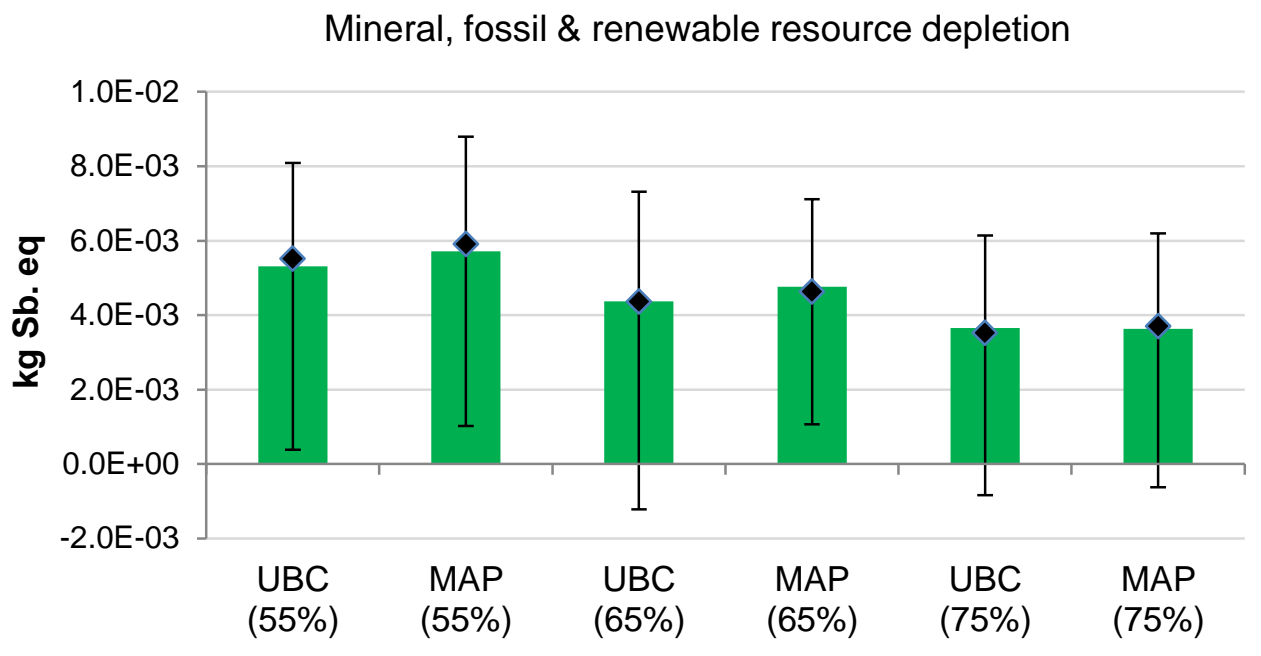

d

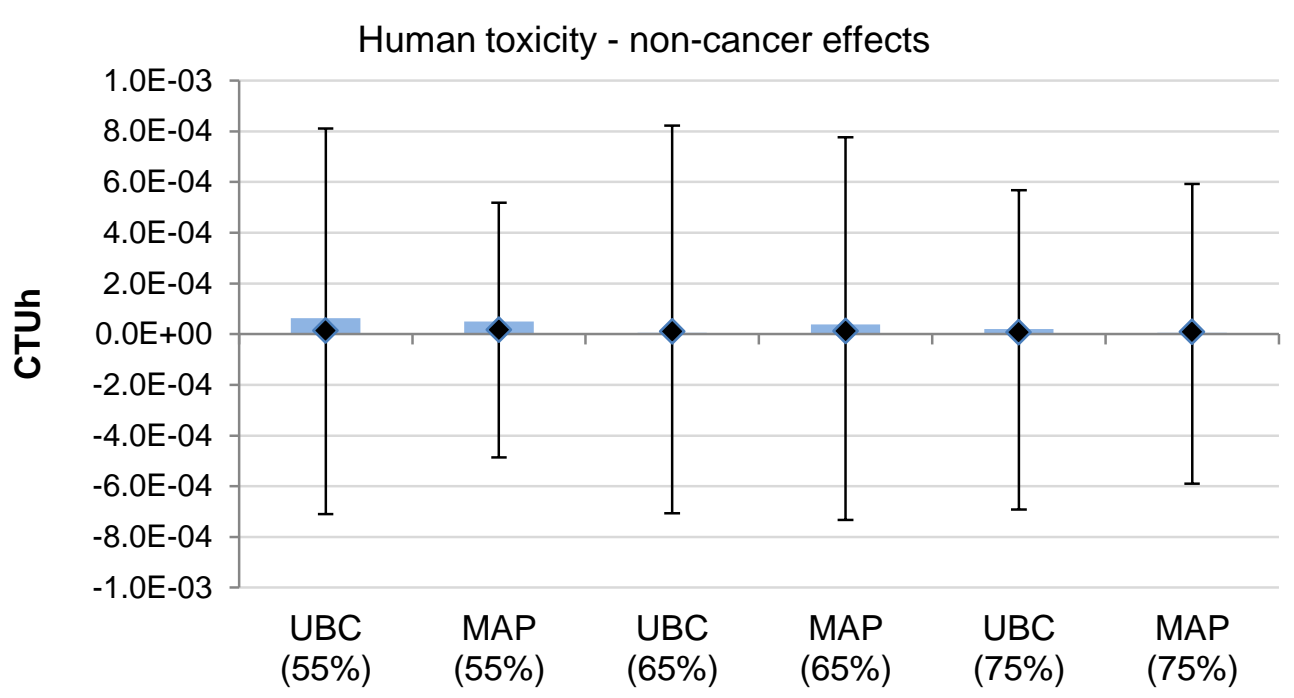

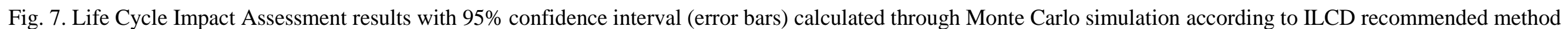

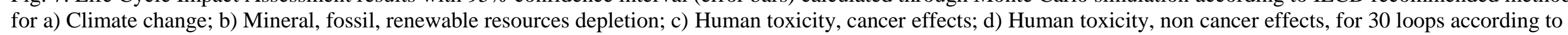


the two alternative scenarios (MAP=Mixed Aluminium Packaging, UBC=Used Beverage Can) and the three values for RR=55\%, 65\%, 75\%. The error bars indicate that in $95 \%$ of the cases the LCIA would fall within the range. 